José Florencio F. Lapeña, Jr. MA, MD, 1,2,4 Franco Louie L. Abes, MD, MSc, ${ }^{3,4}$

Mark Anthony T. Gomez, MD, MPM, 25,6 Cesar Vincent L. Villafuerte III, MD, ${ }^{1,4,7}$

Rodante A. Roldan, $\mathrm{MD}^{6}$

Philip B. Fullante, MD, ${ }^{1,4}$

Ryner Jose C. Carrillo, MD, MSc, ${ }^{1,8}$

Justin Elfred Lan B. Paber, MD, ${ }^{9}$

Armando T. Isla, Jr., MD, ${ }^{10}$

Rose Alcances - Inocencio, MD, MOH, ${ }^{11}$

Jose Benedicto A. Cabazor, MD, ${ }^{12}$

Ruzanne M. Caro, MD, ${ }^{13}$

Ma. Fita P. Guzman, MD ${ }^{14}$

'Department of Otorhinolaryngology College of Medicine - Philippine General Hospital

University of the Philippines Manila, Philippines

${ }^{2}$ Department of Otorhinolaryngology

Head and Neck Surgery

East Avenue Medical Center, Diliman, Quezon City

Philippines

${ }^{3}$ Department of Otorhinolaryngology

Head and Neck Surgery

Faculty of Medicine and Surgery

University of Santo Tomas, Manila, Philippines

${ }^{4}$ Department of Otorhinolaryngology

Manila Doctors Hospital, Manila, Philippines

${ }^{5}$ Department of Otorhinolaryngology

Head and Neck Surgery

Jose R. Reyes Memorial Medical Center, Manila, Philippines

${ }^{6}$ Department of Otorhinolaryngology

Head and Neck Surgery

Rizal Medical Center, Pasig City, Philippines

${ }^{7}$ Department of Otolaryngology-

Head and Neck Surgery

Far Eastern University - Nicanor Reyes Medical Foundation

Quezon City, Philippines

${ }^{8}$ Department of Anatomy, College of Medicine, University of the Philippines Manila, Philippines

${ }^{9}$ Department of Otorhinolaryngology Head and Neck Surgery

Zamboanga City Medical Center, Zamboanga City Philippines

\section{Otorhinolaryngology Out-Patient Practice in the "Post"-COVID-19 Era: Ensuring a Balance Between Service and Safety}

\begin{abstract}
Objective: To review available resources and provide evidence-based recommendations that may optimize otorhinolaryngologic out-patient health care delivery in the "post"-COVID-19 era while ensuring the safety of our patients, healthcare workers and staff.
\end{abstract}

Data Sources: Relevant peer-reviewed journal articles; task force, organizational and institutional, government and non-government organization recommendations; published guidelines from medical, health-related, and scientific organizations.

Methods: A comprehensive review of the literature on the COVID-19 pandemic as it pertained to "post"-COVID-19 out-patient otorhinolaryngologic practice was obtained from peer-reviewed articles, guidelines, recommendations, and statements that were identified through a structured search of the data sources for relevant literature utilizing MEDLINE (through PubMed and PubMed Central PMC), Google (and Google Scholar), HERDIN Plus, the World Health Organization (WHO) Global Health Library, and grey literature including social media (blogs, Twitter, LinkedIn, Facebook). In-patient management (including ORL surgical procedures such as tracheostomy) were excluded. Retrieved material was critically appraised and organized according to five discussion themes: physical office set-up, patient processing, personal protection, procedures, and prevention and health-promotion.

Conclusion: These recommendations are consistent with the best available evidence to date, and are globally acceptable while being locally applicable. They address the concerns of otorhinolaryngologists and related specialists about resuming office practice during the "post"-COVID-19 period when strict quarantines are gradually lifted and a transition to the "new" normal is made despite the unavailability of a specific vaccine for SARS-CoV-2. While they target practice settings in the Philippines, they should be useful to ENT (ear, nose \& throat) surgeons in other countries in ensuring a balance between service and safety as we continue to serve our patients during these challenging times.

Keywords: COVID-19; SARS-CoV-2; otorhinolaryngology; otolaryngology head and neck surgery; ENT; out-patient practice; clinic practice 


\begin{abstract}
${ }^{10}$ Mercy Community Hospital, Iligan City Lanao del Norte, Philippines

"Energy Development Corporation, Ortigas Center Pasig City, Philippines
\end{abstract}

${ }^{12}$ Metro North Medical Center and Hospital Quezon City, Philippines

${ }^{13}$ Capitol Medical Center, Quezon City, Philippines

${ }^{14}$ Asian Hospital and Medical Center, Alabang Muntinlupa City, Philippines
Correspondence: Prof. Dr. José Florencio F. Lapeña, Jr. Department of Otorhinolaryngology Ward 10, Philippine General Hospital

Taft Avenue, Ermita, Manila 1000

Philippines

Phone: (632) 85548467

Telefax: (632) 85244455

Email: lapenajf@upm.edu.ph, jflapena@up.edu.ph

The authors declared that this represents original material that is not being considered for publication or has not been published or accepted for publication elsewhere, in full or in part, in print or electronic media; that the manuscript has been read and approved by the authors, that the requirements for authorship have been met by each author, and that all the authors believe that the manuscript represents honest work.

Disclosures: The authors signed disclosures that there are no financial or other (including personal) relationships, intellectual passion, political or religious beliefs, and institutional affiliations that might lead to a conflict of interest.
The novel Coronavirus 2019 (COVID-19) pandemic has become the singular defining feature of the year 2020.' Caused by the SARS-CoV-2, ${ }^{2,3}$ it has quickly spread to every continent and taken a devastating toll on human lives, resources, systems and institutions. ${ }^{4-6}$ Despite various efforts to contain the virus, slow its spread, and "flatten the curve,",7,8 the end seems nowhere in sight, with no available vaccine in the near future ${ }^{9,10}$ and achieving natural herd immunity fraught with unacceptably high mortalities. ${ }^{11,12}$ Asymptomatic transmission, possible relapse, re-infection of or reactivation among previously-healed patients, ${ }^{13-15}$ and detection of virus in tears, ${ }^{16,17}$ saliva, ${ }^{18}$ mucus, nasopharyngeal, oropharyngeal, tracheobronchial secretions, even feces ${ }^{19-21}$ that can be transmitted via droplets, direct contact, fomites ${ }^{22}$ and even aerosolization, ${ }^{23}$ are among the many possible reasons for the continuing menace.

Otorhinolaryngologists are particularly susceptible to direct infection from viral particles in the nose, nasopharynx, oral cavity, oropharynx, and tracheobronchial tree. ${ }^{24}$ Indeed, the first physician to die worldwide during the initial COVID-19 outbreak in Wuhan, China was an otolaryngologist. ${ }^{25} \mathrm{As}$ direct examination of the ears, nose, throat, head and neck, and aerosolgenerating procedures (AGPs) including ear-cleaning (which may stimulate a cough reflex) constitute a very high level of occupational exposure to SARS-CoV-2, the resumption of office practice even as enhanced extended community quarantine (ECQ) restrictions and lockdowns are gradually eased, become a major concern in the "post'-COVID-19 era before a vaccine is available and herd immunity is achieved. ${ }^{26-28}$

This article aims to review available resources and provide evidence-based recommendations that may optimize otorhinolaryngologic out-patient health care delivery in the "post"-COVID-19 era while ensuring the safety of our patients, healthcare workers, and staff.

\section{METHODS}

A comprehensive review of the literature on the COVID-19 pandemic as it pertained to "post"-COVID-19 out-patient otorhinolaryngologic practice was obtained from peer-reviewed journal articles, task force and organizational, government and non-government organization recommendations, published guidelines from medical, health-related, and scientific organizations.

Articles, guidelines, recommendations, and statements were identified through a structured search of the data sources for relevant literature utilizing MEDLINE (through PubMed and PubMed Central PMC), Google (and Google Scholar), HERDIN Plus, the WHO Global Health Library, and grey literature including social media (blogs, Twitter, Linkedln, Facebook).

Data sources were queried for studies and articles related to evolving epidemiology (including re-conversion to positive status), clinical presentation (including neurologic and otolaryngologic symptoms, asymptomatic individuals and carriers), transmission and contamination (including droplets, aerosolization, oral-fecal route, fomites), and diagnosis (including symptoms, signs, imaging, other labs, and tests - rt-PCR \& rapid $\lg G / \lg M$ ). These were reviewed to support a general recommendation to consider all patients encountered as potentially COVID-19 positive. In-patient management (including ORL surgical procedures such as tracheostomy) was excluded.

Relevant search terms used alone and in combination included: "COVID-19," "SARS-CoV-2," 


\section{REVIEW ARTICLE}

"Coronavirus", "virus", "Otorhinolaryngology," "Otolaryngology," "ENT," "Head and Neck Surgery," "Facial Plastic Surgery," "Craniomaxillofacial Surgery," "Office Practice," "Clinical Practice," "Office Procedures," "Out-Patient," "Ambulatory," "Telemedicine," "viral particles," "aerosol," "aerosol generating procedures," "disinfection," "antiseptics", "PPE," "personal protection," "respiratory protection," "personal protective equipment," "endoscopy," "rhinoscopy," "pharyngoscopy," "laryngoscopy" "prevention", "health promotion", "re-emergence."

Retrieved material was critically appraised and reviewed, and recommendations were formulated organized according to five discussion themes: 1. physical office set-up; 2. patient processing; 3. personal protection; 4. procedures; and 5. prevention and healthpromotion. The draft recommendations were externally reviewed by otolaryngologist-clinical epidemiologists who were asked to critique, comment on, suggest corrections, check consistency, and correct references or suggest additional or better references. They were asked to determine whether the recommendations were relevant to clinical practice in the setting(s) they were intended for. Following review, the recommendations were revised accordingly, citing additional evidence as needed. A cut-off for citations was set on 2020 May 10 after all post-review revisions had been completed.

\section{DISCUSSION}

The "post"-COVID-19 era is envisioned to continue until such time that a vaccine is widely available, ${ }^{9}$ and/or natural herd immunity has been achieved for the current strains. ${ }^{12}$ Following this, the possibility of seasonal re-emergence (similar to influenza) must also be considered. During the "post"-COVID-19 era, our primary and overarching recommendation is to consider all patients encountered as potentially COVID-19 positive. ${ }^{29}$ This is not only based on documented infectivity by asymptomatic individuals and super carriers, ${ }^{30,31}$ but by cases of possible re-infection as well among previously recovered patients. ${ }^{32}$ Such a stance is reflected in our recommendations, grouped into five main discussion themes.

\section{PHYSICAL OFFICE SET-UP}

\section{Post visual alerts at the entrance to health-care facilities reminding} all persons to wear a mask (and practice respiratory hygiene/ cough etiquette) before entering.

The postage of signages in appropriate languages at the entrance and inside the clinic to alert patients with respiratory symptoms serves to notify staff as well as to teach/remind patients and companions about correct respiratory hygiene and cough etiquette. ${ }^{33}$ Paper signages need to be replaced regularly to keep them clean, or covered in clear plastic and cleaned daily. Practitioners may opt not to see any symptomatic, probable, or suspect patients in their private clinics; a notice to this effect may be posted outside the office, requesting such patients to report directly to the appropriate facility for screening. ${ }^{34}$

Previously the World Health Organization (WHO) advised that only individuals with symptoms or those taking care of at-risk people should use masks. ${ }^{35}$ Subsequently, both the US ${ }^{36}$ and Singapore ${ }^{37}$ switched to advising citizens to wear masks when they leave their homes. The Philippines requires masks (whether cloth or surgical) be worn outside one's residence, ${ }^{38}$ with some areas implementing this more strictly than others. ${ }^{39}$ The US Centers for Disease Control and Prevention (US CDC) now recommends wearing cloth face coverings in public settings where other social distancing measures are difficult to maintain especially in areas of significant community-based transmission although it still maintains that the cloth face coverings recommended are not surgical masks or N-95 respirators. ${ }^{36}$ Those are critical supplies that must continue to be reserved for healthcare workers and other medical first responders. ${ }^{36}$ Furthermore, patients are advised to keep masks on in reception areas and other first contact locations for patients and visitors. ${ }^{40}$

\section{Consider installing a disinfection doormat at the building or floor entrance or clinic entrance.}

Viral particles in footwear have been well documented ${ }^{41}$ leading to recommendations to leave footwear outside homes ${ }^{42}$ and to change footwear or use booties or shoe covers inside health care facilities (although there is no good evidence for booties or shoe covers). ${ }^{43}$ When footwear cannot be removed or covered, stepping in footbaths may be considered to reduce viral load. Commerciallyavailable disinfection mats use various disinfectants (aldehydes, quaternary ammonium compounds, phenolics, and halogens) to safely kill viruses. ${ }^{44}$ Alternatively, a chlorinated doormat or towel soaked in 0.5\% (1:10) bleach solution (1 part sodium hypochlorite in 9 parts water) ${ }^{45}$ may be installed outside the clinic (followed by a dry rug), or at the entrance to the building or floor (outside the lift) to prevent tracking mud into the clinic. Visibly dirty doormats should be cleaned or replaced.

\section{Disinfect doorknobs or handles regularly, or install hands-free door handles.}

The first and last surface contact for persons entering and exiting the clinic should be regularly disinfected, using 60-90\% isopropyl or ethyl alcohol spray or wipe. ${ }^{46}$ This measure is more effective than 
asking patients and accompanying persons to wear gloves. ${ }^{47}$ Handsfree alternatives, such as twist handles that can be operated by elbow-pressure, or foot-handles may be installed.

Patients and accompanying persons should be seated at least 2 meters apart inside the clinic and in the waiting area.

This measure serves to establish physical distancing between patients and accompanying persons as well as clinic staff. The WHO and Philippine DOH (Department of Health) recommend at least a 1-meter distance. ${ }^{48,49}$ The US CDC recommends maintaining a distance of at least 6 feet ( 2 meters). ${ }^{50}$

A study on the transmission of influenza showed that at a distance of 1 meter, the average cough centre-line velocity measured 1 meter away from the mouth was $1.2 \mathrm{~m} / \mathrm{s}^{51}$ In a room with an infected person with ineffective and inadequate ventilation, the concentration of the virus in the air of the room can build up, and the distance of $6 \mathrm{ft}$ ( 2 meters) is not sufficient to protect against infections. ${ }^{52}$ People who are obviously sick and coughing are likely to spread droplets containing coronavirus particles further than people who are simply breathing or talking. Hence, recent literature does not support the 1-2 meter rule of spatial separation and raises concerns about viral transmission even when breathing or talking, ${ }^{53}$ further supporting the use of masks by all persons.

The National University of Singapore recommends that patients be told where exactly to be seated in the waiting area and that seats outside the consultation room should be spaced 2 meters apart. ${ }^{54}$ A small clinic can practice this by only admitting one patient at a time, with physical-distancing markers (or seats) placed outside. Accompanying persons can also be limited to those with patients who are children, elderly or infirm.

\section{Consider installing physical barriers such as clear plastic sneeze guards.}

Source control measures for all persons with respiratory symptoms include respiratory hygiene/cough etiquette. ${ }^{55}$ In order to prevent the transmission of all respiratory infections in healthcare settings, implementation of control measures should be done at the first point of contact with a potentially infected person. ${ }^{56}$ In a typical otolaryngology clinic, the first point of contact are the waiting rooms. Waiting rooms provide potential opportunities for transmission of infections transmitted via droplet and airborne routes. ${ }^{57}$

The US Occupational Safety and Health Administration recommends where possible, to install physical barriers such as clear plastic sneeze guards in reception or intake areas. ${ }^{58}$ The use of barrier protections, such as sneeze guards, is common practice for both infection control and industrial hygiene. ${ }^{50}$

However, physical barriers have the potential to serve as sources of infection, and should be disinfected after every patient encounter, cleaned after every clinic day and changed whenever transparency is reduced. ${ }^{55}$ Barriers should be firmly fixed in order to prevent accidental dislodgement and contamination of people on either side. They can also impede ventilation and laminar flow of air, trap heat and humidity and limit visibility for both patients and clinicians so care must be exercised in setting them up.

Examples of such barriers have been produced locally using $0.25^{\prime \prime}$ thick clear acrylic, extra thick 300 micron clear acetate, or thick plastic sheets and can be installed around the reception desk (Figure 1A), between physician desks and patient chairs (Figure 1B), or around examination chairs (Figure 1C).

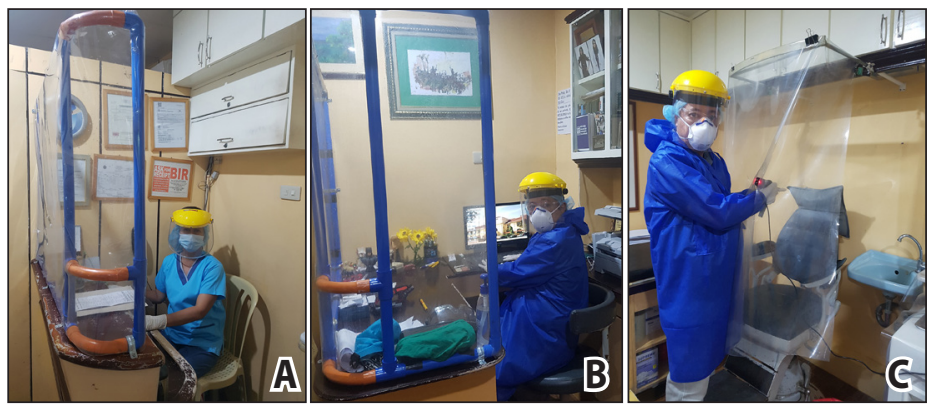

Figure 1. Physical office barriers in ENT clinic, General Santos City: A. reception area; B. consultation desk; and C. examination chair. Courtesy of Dr. Cesar Anthony P. Yabut. (Photos published in full, with permission)

\section{Specialized negative-pressure ventilation should ideally be installed in otolaryngology clinics for AGPs.}

A study published in Emerging Infectious Diseases found a wide distribution of COVID-19 virus genetic material on surfaces and in the air about 4 meters ( 13 feet) from patients in two hospital wards in Wuhan, China. ${ }^{41}$ Aerosolized COVID-19 particles were detected near air vents $(5 / 14[35.7 \%])$, in patient rooms $(8 / 18[44.4 \%])$, and in the doctor's office area (1/8 [12.5\%])..$^{41}$ Aerosolized virus was detected in the airflow upstream from the patients but was concentrated near and downstream of the patients. ${ }^{41}$

Procedures that could generate infectious aerosols should ideally be performed in an Airborne Infection Isolation Room (AllR). ${ }^{59}$ Such AllRs are single-patient rooms at negative pressure relative to the surrounding areas, and with a minimum of 12 air changes per hour $(\mathrm{ACH}){ }^{60}$ Air from these rooms should be ducted to the outside environment after passing through a High-Efficiency Particulate Air (HEPA) filter. ${ }^{59}$

If an AllR is not available, guides for setting up a negative pressure room such as the Minnesota Department of Health comprehensive 


\section{REVIEW ARTICLE}

guide for setting up a negative pressure room to prevent infectious particles from escaping the room envelope ${ }^{61}$ may be consulted.

Salient features for such negative pressure rooms include:

a. pressure differential, Pascals $(\mathrm{Pa})$ of 2.5 Pa measured between room and corridor;

b. recommended air change rate is $12 \mathrm{ACH}$; and

c. air from negative pressure rooms and treatment rooms exhausted directly to the outside if possible. ${ }^{61}$
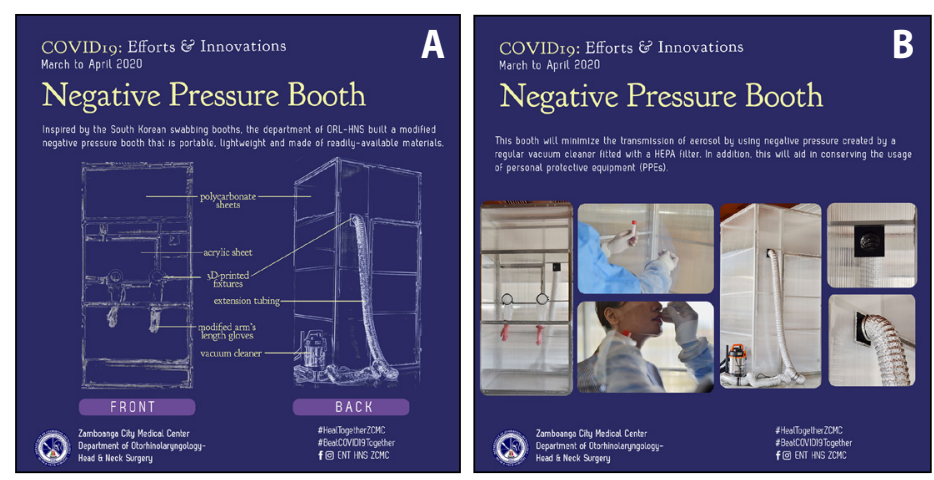

Figure 2. Negative pressure booth: A. Schematic diagram; B. Photos.

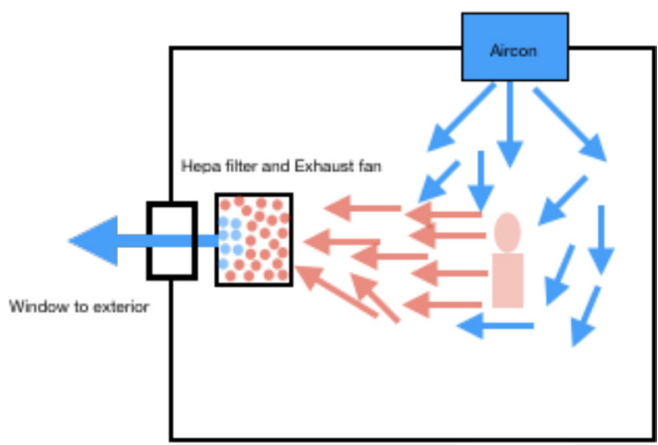

Figure 3. A. Exhaust fan discharging HEPA filtered clean air through an outside-facing window. Solid-fill box, clean air supply; stippled box, HEPA filter and exhaust fan; black-outlined rectangle, window facing outside.

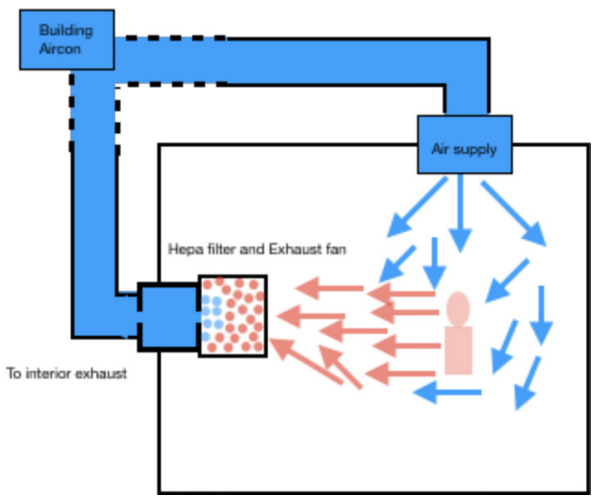

Figure 3. B. HEPA filtered air ducted by exhaust fan to a building exhaust system. Solid-fill box, clean air supply; stippled box, HEPA filter and exhaust fan; black-outlined rectangle and shaded duct leading to interior exhaust.
The Zamboanga City Medical Center Department of Otorhinolaryngology - Head and Neck Surgery under our co-author Dr. Justin Elfred Lan B. Paber has developed special negative pressure examination booths. ${ }^{62}$ (Figure $2 A, B$ )

In existing clinic rooms, negative air pressure can be produced by balancing the air intake (pumped into the room by the air conditioning system) and outflow of air from a room (sucked out by an exhaust fan). Negative pressure rooms have higher outflow than intake rates. A negative pressure room does not need a HEPA filter inside the room because the filter is placed inside the air duct so that air exhausted into the environment is clean.

There are two possible ways of exhausting filtered air from negative pressure rooms. In Figure $3 A$, the exhaust fan draws HEPAfiltered room air outside through a window. If a window is not available, the filtered air can be ducted to the building exhaust system as seen in Figure 3B. Because the discharged air is HEPA filtered, no extra consideration for air discharge location is required. ${ }^{61}$

Without such negative pressure, air-conditioned rooms are vulnerable, as air conditioning may circulate infectious droplets containing SARS-CoV-2. A previous report showed how one asymptomatic diner managed to infect diners away from him as infectious droplets were circulated by the air conditioning system. ${ }^{63}$ Virus-laden aerosols mainly concentrate near and downstream of airflow from the patients although risk was also present in the upstream area. ${ }^{41}$

An easy way to induce negative pressure in a windowless room (if there is an exhaust fan in the bathroom) is to open the bathroom door and keep the aircon unit running. If the exhaust fan is appropriate to the size of the room and there are no obstructions to air flow, then it can efficiently drain air out of the room. Because "air from toilet rooms or other soiled areas is usually exhausted directly to the atmosphere through a separate duct exhaust system," ${ }^{\prime \prime 0}$ a portable HEPA filter can help keep viral load down if there is enough air change inside the room.

Regular cleaning and decontamination of the clinic and clinic facilities is recommended. Appropriate and recommended products should be used on both hard and soft surfaces. Cleaning and decontamination of clinic instruments and electronic items (i.e. tablets, monitors, keyboards, etc.) should follow manufacturer's instructions.

The virus that causes coronavirus disease 2019 (COVID-19) is stable for several hours to days in aerosols and on surfaces. ${ }^{64}$ Severe acute respiratory syndrome coronavirus 2 (SARS-CoV-2) was detectable in aerosols for up to three hours, up to four hours on copper, up to 
24 hours on cardboard and up to two to three days on plastic and stainless steel..$^{64}$ These findings affirm the US CDC guidance on the cleaning of frequently touched objects and surfaces. ${ }^{65}$

The United States Environmental Protection Agency (EPA) has a list of chemicals and products for use against SARS-CoV-2. ${ }^{66}$ When using an EPA-registered disinfectant, follow the label directions for safe, effective use. Make sure to follow the contact time, which is the amount of time the surface should be visibly wet. ${ }^{66}$ The Philippine $\mathrm{DOH}$ recommends the use of $0.5 \%(1: 10)$ bleach solution (1 part sodium hypochlorite in 9 parts water) for surface disinfection. ${ }^{45}$

Best practices in reprocessing reusable and single-use devices in otolaryngology, with particular attention to flexible fiberoptic endoscopes/nasopharyngoscopes, nasal speculums, and other clinic and operating room instruments should be observed (see section on procedures). Reprocessing standards should be based on risk level. High-risk devices require sterilization, whereas lower risk devices may be reprocessed using various disinfection procedures. ${ }^{67}$ Among these procedures are initial cleaning with soap and water, soaking in or wiping with disinfectant solution, autoclaving, microwave, and ultraviolet (UV) light.

The clinic should maintain a supply of instrument sterilants or disinfectants that are readily available for Philippine use. Among those recommended by the US FDA are high-level disinfectants $2.4 \%$ glutaraldehyde (Cidex ${ }^{\oplus}$ ) which can be used for a 45 minute soak (with the solution reusable for 14 days); $3.4 \%$ glutaraldehyde (Cidexplus ${ }^{\circledR}$ ) which can be used for a 20 minute soak (with the solution reusable for 28 days; ${ }^{68}$ and hand and instrument surface disinfectants such as alcohol-based solutions (70\% isopropyl or ethyl alcohol) and propanol-based solutions (Cutasept ${ }^{\oplus}$ and Sterillium ${ }^{\oplus}$ ). Other methods of sterilization include autoclaving and UV light type $C^{67,69,70}$ Caution is advised with using UV light as this may injure skin and eyes. ${ }^{71}$ Cleaning instructions specific to manufacturer's instructions such as the Karl Storz endoscopes can be downloaded from the company website. ${ }^{22}$

\section{UV light may be an effective measure for decontaminating clinic rooms and surfaces, in addition to chemical surface disinfection.}

According to the US CDC, the application of UV radiation in the health-care environment (i.e., operating rooms, isolation rooms, and biologic safety cabinets) is limited to destruction of airborne organisms or inactivation of microorganisms on surfaces. ${ }^{69}$ It may also have use in decontaminating surgical instruments, ${ }^{70}$ and is widely used in various settings, including dental clinics. ${ }^{73}$

No data is available specifically testing the UV susceptibility of the SARS-CoV-2 virus. However, tests on related coronaviruses such as the SARS coronavirus have concluded that they are highly susceptible to UV inactivation. ${ }^{71}$ Considering that the Health Technology Assessment in Ontario was unable to make a firm conclusion about the effectiveness of UV technology on Hospital Acquired Infections, ${ }^{74}$ the use of UV disinfecting devices during the COVID-19 pandemic should be guided by such recommendations as those issued by the US FDA. ${ }^{75}$ Moreover, although a 2012 study concluded that "UV radiation appears to provide a quick alternative disinfection technique to chemical disinfectants (e.g. ethanol) for some surgical tools that is less harmful to both humans and fish while not producing chemical waste," it does "not recommend using this method for tools such as needle holders having overlapping parts or other structures that cannot be exposed directly to UV radiation. ${ }^{176}$

\section{Special guidelines are recommended for the use and disinfection of washrooms and toilets.}

Because of the possibility of oral-fecal transmission of SARSCoV-2, ${ }^{77,78}$ clinics should determine their own guidelines for the use and disinfection of washrooms and toilets. Apart from viral shedding from the upper airway, aerosolization of the virus from excreta possibly during valsalva or during flushing may also occur and may lead to droplets that may be inhaled by the next toilet user or may persist on hard surfaces such as tiles, mirrors and faucets. ${ }^{79}$ Therefore, as much as possible, patients and companions should not use clinic washrooms and toilets (using building facilities if available). Using negative-pressure exhaust fans and closing the lid before flushing to minimize aerosol generation in addition to strict hand washing before and after using the washroom or toilet, and disinfecting doorknobs, tap and flush handles, and light switches (or installing no-touch faucets and switches) are some measures to consider. ${ }^{80}$ In addition, periodic cleaning with detergent and chemical surface disinfection plus UV light (if available) before closing the clinic for the day are recommended. ${ }^{81}$

\section{No touch disposal of all clinic-generated waste as biohazardous waste is recommended.}

To be consistent with our overarching recommendation to consider all patients as potentially COVID-19 positive, all clinicgenerated waste material should be considered biohazardous waste and disposed of accordingly. ${ }^{82}$ Clearly marked biohazard bags, or yellow garbage-disposal bags should be sealed and disposed of according to local health code standards. Unfortunately, such standards vary widely, and generate enormous COVID-19 hazardous waste, especially in resource-challenged low- and middle-income country settings. The Asian Development Bank has compiled a list 


\section{REVIEW ARTICLE}

of considerations and recommendations that should be consulted in this regard. ${ }^{83}$

\section{PATIENT PROCESSING}

Optimizing the otorhinolaryngologic - head and neck surgery (ORL-HNS) physician-patient clinical encounter during the COVID-19 pandemic entails ensuring the safety of everyone involved including the patient, accompanying persons, health care workers (HCW), and auxiliary staff. This can be done by promoting telemedicine, and when actual consultation is required, by focusing on actionable steps prior to, during, and after each patient encounter. Here are some recommendations:

\section{Telemedicine should be utilized as much as possible to lower risk of exposure for patients and physicians.}

Telemedicine should be utilized as much as possible during the COVID-19 pandemic for its ability to provide patient care without the need to go to the hospital or clinic. Through this avenue, patients with symptoms such as cough or colds can still be managed and monitored appropriately in the safety of their homes. This decongests health facilities and allocates resources to those who really need faceto-face care. Moreover, teleconsults also reduce viral transmission for both patients and healthcare staff. ${ }^{84}$

Telemedicine has been used by ORL specialists in the USA. In a retrospective cohort study of 1,385 ENT encounters with 2,008 individual diagnoses at the US Veteran Affairs Medical Center, the rate of telemedicine eligibility among outpatient consults in a general otolaryngology practice was $62 \% .{ }^{85}$ Problems of the middle and inner ear were most eligible because they do not commonly require a procedure to reach a diagnosis. Conditions affecting the larynx and outer ear were the least eligible. ${ }^{85}$

Although rules in the USA were relaxed in response to the COVID-19 crisis, the Amercan Academy of Otolaryngology - Head and Neck Surgery (AAO-HNS) Telemedicine Committee emphasized that healthcare providers still have the responsibility to ensure privacy and manage encryption settings of the applications. Approved remote communication products include Apple Face Time, Facebook Messenger video chat, Google Hangouts video and Skype. ${ }^{86}$

In the Philippines, medical consultations over the phone, by chat, short messaging service (SMS), and other audio and videoconferencing platforms (such as Viber, WhatsApp, Telegram, and Zoom) fall within the scope of telemedicine. ${ }^{87}$ Physicians have utilized communication applications such as Viber, Facebook Messenger and direct SMS or text messaging. Some physicians have also utilized applications created for teleconsults such as SeriousMD (https://seriousmd.com) and Medifi (https://www.medifi.com) that provide electronic medical records and prescriptions as well as facilitate professional fee collection using debit or credit cards.

The Philippine DOH collaborated with the National Privacy Commission (NPC) to provide 24/7 hotlines (TeleMED Management, Medgate, Globe Telehealth, Inc. or KonsultaMD) that can connect patients to volunteer doctors for free consults. This service is limited to the National Capitol Region (NCR) but more collaborations are underway for expansion to other regions. ${ }^{87}$

Being a COVID-19 referral center, the University of the PhilippinesPhilippine General Hospital (UP-PGH) collaborated with Phillppine Long Distance Telephone Compnay (PLDT) to provide a hotline for the COVID-19 Bayanihan Operations Center allowing patients to consult with professionals regarding their symptoms and coordinate transfers from other hospitals. Notably, this hotline also facilitates receiving donations and supplies such as personal protective equipment (PPE) ${ }^{88}$

\section{Prior to the patient clinical encounter, all efforts should be made to screen, triage, and isolate patients who are suspected to have or are positive for COVID-19, according to existing protocols.}

As discussed in the previous recommendation, patients can be advised to tele-consult remotely from home beforehand in order to screen for symptoms and to provide a designated appointment time in order to minimize the number of patients accommodated at the facility at a particular time. They can also be advised to wait outside the clinic while awaiting their turn. ${ }^{59,89}$ If unable to do prior teleconsultation remotely from home, consideration for developing an on-site system where the patient can be interviewed in a separate area with the aid of phone or web cameras and microphones can be used in order to pre-screen the patient prior to face-to-face consultation. History taking and inspection of easily visible areas can be done using the said phone or web cameras. In addition, vital signs measurement using commonly available household instruments such as digital thermometers, and self-administered automated BP monitors can be used during remote site evaluation.

The US CDC recommends developing protocols so that the clinic or health care facility can triage and assess patients prior to or immediately upon entry. ${ }^{89}$ Everyone, including patients, staff, and HCWs should be actively screened for fever and other symptoms of COVID-19. ${ }^{59} \quad$ Use of screening questionnaires according to updated case definitions can be helpful to systematize the process. ${ }^{90}$ Examples of screening questionnaires include but are not limited to: 1) the Philippine Society of Otolaryngology-Head and Neck Surgery (PSO-HNS) COVID-19 screening and triaging tool for use in the out- 
patient clinic; ${ }^{91}$ and 2) the American Health Care Association and National Center of Assisted Living COVID-19: screening checklist - for visitors and staff. ${ }^{92}$

Ideally, all patients attending the out-patient clinic should have their temperatures checked on arrival, and patients who probably have, or are suspected to have COVID-19 should be directed to the nearest hospital emergency room (or closest COVID-19 triage center or Barangay Health Emergency Response Team (BHERT) for further evaluation. ${ }^{25,34}$ The use of other tools for screening such as pulse oximetry testing for 02 desaturation have also been suggested, ${ }^{93}$ but there are as yet no published studies to support its use for screening, as well as conflicting public opinion on its utility for screening. ${ }^{94,95}$

During the patient clinical encounter, all steps should be taken so that it is safe, efficient, and effective. Suggestions include but are not limited to pre-screening and prior history taking to optimize time spent during the in-person clinical encounter; using a directed physical examination; minimizing number of exposed staff; and ensuring use of appropriate Personal Protective Equipment (PPE) and an optimized clinic set-up.

The initial patient encounter with the receptionist or secretary (after initial screening) begins with ensuring compliance with proper wearing of masks, performing hand hygiene and observing physical distancing in the waiting area. This encounter usually includes handling of referral notes, filling out or updating hard-copy or electronic medical records, and obtaining vital signs. Physicians and clinic staff may agree on modified procedures that entail less contact (such as foregoing with routine sphygmomanometry and taking the pulse and respiratory rate), and only obtaining weight (especially for children) during this period.

With regards to the actual physician - patient encounter, the United Kingdom's Ministry of Health recommends that whenever face-to-face contact is essential, this should be kept to 15 minutes or less wherever possible. ${ }^{96}$ This is echoed by the US CDC which recommends the use of telemedicine in order to reduce facility risk. ${ }^{59}$ The usual paraphernalia for this encounter may be minimized during this period. For instance, only an ear speculum and curette may be prepared (without a nasal speculum, cheek retractor, tongue depressor, and mirrors) for a routine work-clearance otologic referral for ear cleaning. The section on procedures discusses this further.

Specific guidance on the head and neck patient clinical encounter during the COVID-19 pandemic from Givi, et al. include:29 1) that the examination be preferably performed in a separate room away from other patients, 2) only the necessary personnel should be present, 3) examination should be performed by the most experienced person present, and might be a more focused assessment based on the judgement of the examining physician; and that 4) proper doffing and disposal of PPE are of utmost importance. More detailed recommendations are in our section on procedures.

The World Health Organization (WHO) also recommends the following administrative measures among others: provision of adequate training for $\mathrm{HCWs}$; ensuring an adequate patient-to-staff ratio; monitoring $\mathrm{HCW}$ compliance with standard precautions and providing mechanisms for improvement as needed..$^{90}$

If patients seen in clinic are subsequently found to be positive for COVID-19, there should be a system to trace and isolate them as soon as possible and perform immediate contact-tracing of all persons present in the clinic around the same time. Patients and possible contacts should then be managed accordingly depending on prevailing protocols of the $\mathrm{DOH}$, local government unit, and of the individual health care facility.

After the patient clinical encounter, steps should be taken to minimize transmission following possible SARS-CoV-2 exposure. All staff should continue observing proper hand hygiene and avoid touching the mucosal surfaces of the face (eyes, mouth, nose); the use of electronic medical records, electronic prescriptions, and cashless billing to minimize transfer of the virus through fomites (e.g. physical chart, prescription forms, or cash) should be considered; and there should be proper disinfection of the patient area and used instruments.

All clinic staff should clean visibly unsoiled hands with an alcoholbased hand rub or $70 \%$ alcohol or better yet, wash them properly with soap and water before and after each patient encounter. ${ }^{97}$ Clinic staff should avoid touching their face (especially the eyes, mouth or nose). ${ }^{98}$

Following the consultation session, measures should be put in place for processing laboratory requests, prescriptions, referrals to other physicians or health professionals, and other communications. While electronically - generated paperless communications are ideal, careful handling of hard-copy materials emanating from the consultation area should ensure protection of clinic staff and patients. Many receptionists and secretaries double-check these materials and reiterate instructions and follow-up schedules to patients and accompanying persons. The use of appropriate PPE (including gloves, masks and face shields) should be practiced. Extra care should be taken in handling payments. Although cashless means of payment have been recommended by some, ${ }^{99}$ many payments are made in bills and coins. Because"there is currently no evidence to confirm or disprove that COVID-19 can be transmitted through coins 


\section{REVIEW ARTICLE}

or banknotes,"100 cash should be treated as contaminated material which should be stored in a covered container and handled with gloves. A process for safely handling payments should be established by each clinic.

The WHO reports that the COVID-19 virus has been shown to survive for up to 72 hours on stainless steel and plastic, less than 24 hours on cardboard, and less than 4 hours on copper. ${ }^{98,64}$ Therefore, handling of these fomites can transmit the virus through direct contact. Post-consultation cleaning and disinfection are discussed further in our sections on physical office set-up and procedures.

\section{PERSONAL PROTECTION}

Personal Protective Equipment (PPE): ORL specialists and their staff should be familiar with types and levels of appropriate PPE.

Routine otorhinolaryngological (ORL), head and neck examinations and office procedures pose significant risk of COVID-19 viral transmission. Due to the risk, office procedures such as those concerning the upper airway like nasal or laryngeal endoscopy should be deferred unless absolutely necessary or until COVID-19 diagnostic tests are negative. ${ }^{27,101}$ But since many of the ORL cases present with urgent life-threatening conditions such as airway compromise, some procedures need to be done right away without prior COVID-19 diagnostic testing. Thus, it is highly important that ORL specialists and their staff protect themselves with appropriate PPE.

As defined by the WHO, PPE is equipment worn to minimize exposure to occupational hazards such as the SARS-COV-2 virus that causes COVID-19.90 Proper PPE usage is important in prevention and control of spread of the disease. ${ }^{90}$ In the setting of the COVID-19 pandemic, there are various systems that classify PPEs or combinations of PPEs according to the setting. Two examples are summarized in Table 1.

Use of PPE in ORL out-patient Clinics: ORL specialists and their clinic staff should always wear appropriate PPEs such as gloves, protective clothing, face shields and respirators, during a patient encounter in the outpatient, ambulatory care setting.

China reported that 2,055 of its health workers were infected by SARS-CoV-2 at the start of the epidemic with 22 deaths. ${ }^{105}$ Chinese authorities attributed these to the apparent inadequacy of personal protection for HCWs in the early days or weeks of the epidemic as well as prolonged interaction with infected patients. ${ }^{105}$ Interestingly, they also mentioned the weak sense of awareness for the need for strong personal protection among their HCWs. ${ }^{105}$ Italy likewise reported that about 5,000 of their HCWs were infected by the SARS-CoV-2 virus due to lack of protective clothing and equipment during the onset of the
Table 1. Levels of personal protective equipment for health care workers

\begin{tabular}{|c|c|c|c|}
\hline \multicolumn{2}{|c|}{$\begin{array}{l}\text { Philippine General } \\
\text { Hospital-Hospital } \\
\text { Infection Control Unit }{ }^{102,103}\end{array}$} & \multicolumn{2}{|c|}{$\begin{array}{l}\text { National Health Service, United } \\
\text { Kingdom }^{104}\end{array}$} \\
\hline Level & PPE & Level & PPE \\
\hline \multirow[t]{3}{*}{ Level 1} & $\begin{array}{l}\text { Goggles } \\
\text { Surgical mask or } \\
\text { Face shield }\end{array}$ & & \\
\hline & & $\begin{array}{l}\text { Level } 1 \\
\text { Standard } \\
\text { Infection Control } \\
\text { Procedures } \\
\text { (SICP) }\end{array}$ & $\begin{array}{l}\text { Disposable apron } \\
\text { - Disposable gloves } \\
\text { Consider (if risk of } \\
\text { spraying or splashing): } \\
\text { - Fluid-resistant Type IIR } \\
\text { surgical face mask \& full } \\
\text { face visor or goggles }\end{array}$ \\
\hline & & $\begin{array}{l}\text { Level } 2 \\
\text { CONTACT } \\
\text { DIRECT or } \\
\text { INDIRECT } \\
\text { CONTACT } \\
\text { PRECAUTIONS }\end{array}$ & $\begin{array}{l}\text { - Disposable apron } \\
\text { - Fluid-resistant disposable } \\
\text { gown } \\
\text { - Disposable gloves } \\
\text { Consider (if risk of } \\
\text { spraying or splashing): } \\
\text { - Fluid-resistant Type IIR } \\
\text { surgical face mask } \\
\text { - Goggles or full face visor }\end{array}$ \\
\hline \multirow[t]{2}{*}{ Level 2} & $\begin{array}{l}\text { Cap } \\
\text { Goggles } \\
\text { N95 respirator } \\
\text { Gloves } \\
\text { Gown or coverall }\end{array}$ & & \\
\hline & & $\begin{array}{l}\text { Level } 2 \\
\text { DROPLET } \\
\text { DROPLET } \\
\text { PRECAUTIONS }\end{array}$ & $\begin{array}{l}\text { - Disposable apron } \\
\text { - Consider fluid-resistant } \\
\text { disposable gown if apron } \\
\text { provides inadequate } \\
\text { cover for the procedure/ } \\
\text { task being performed } \\
\text { - Disposable gloves } \\
\text { - Fluid-resistant Type IIR } \\
\text { surgical face mask and } \\
\text { goggles OR fluid-resistant } \\
\text { Type IIR surgical face } \\
\text { mask and full face visor }\end{array}$ \\
\hline Level 3 & $\begin{array}{l}\text { Cap } \\
\text { Goggles and face } \\
\text { Shield } \\
\text { N95 respirator } \\
\text { Gloves } \\
\text { Shoe covers } \\
\text { Surgical gown } \\
\text { Scrub suits }\end{array}$ & & \\
\hline
\end{tabular}




\begin{tabular}{|c|c|c|c|}
\hline \multicolumn{2}{|c|}{$\begin{array}{l}\text { Philippine General } \\
\text { Hospital-Hospital } \\
\text { Infection Control Unit }{ }^{102,103}\end{array}$} & \multicolumn{2}{|c|}{$\begin{array}{l}\text { National Health Service, United } \\
\text { Kingdom }^{104}\end{array}$} \\
\hline Level & PPE & Level & PPE \\
\hline & & $\begin{array}{l}\text { Level } 2 \\
\text { AIRBORNE } \\
\text { AIRBORNE } \\
\text { PRECAUTIONS }\end{array}$ & $\begin{array}{l}\text { - Disposable apron } \\
\text { - Consider fluid-resistant } \\
\text { disposable gown if apron } \\
\text { provides inadequate } \\
\text { cover for the procedure/ } \\
\text { task being performed } \\
\text { - Disposable gloves } \\
\text { - Filtering face piece } 3 \\
\text { (FFP3) respirator and eye } \\
\text { protection or a powered } \\
\text { hood respirator }\end{array}$ \\
\hline \multirow[t]{2}{*}{ Level 4} & $\begin{array}{l}\text { Coveralls } \\
\text { Surgical caps } \\
\text { Goggles/Face } \\
\text { Shield } \\
\text { N95 respirator / } \\
\text { PAPR(Powered, } \\
\text { air purifying } \\
\text { respirator) } \\
\text { Double gloves } \\
\text { Shoe covers } \\
\text { Dedicated shoes } \\
\text { Scrub suits }\end{array}$ & & \\
\hline & & $\begin{array}{l}\text { Level } 3 \\
\text { ENHANCED }\end{array}$ & $\begin{array}{l}\text { - Reinforced fluid-resistant } \\
\text { long-sleeve surgical } \\
\text { gown } \\
\text {. Disposable fluid-resistant } \\
\text { hood (if wearing a gown } \\
\text { without an attached } \\
\text { hood) } \\
\text { - Full length disposable } \\
\text { plastic apron } \\
\text { FFP3 respirator or } \\
\text { powered hood respirator } \\
\text { - Disposable full face visor } \\
2 \text { sets of long or extended } \\
\text { cuff non-sterile, non-latex } \\
\text { disposable gloves } \\
\text { - Surgical wellington boots } \\
\text { or closed shoes } \\
\text { Disposable boot covers }\end{array}$ \\
\hline
\end{tabular}

Note: The blank cells in rows indicate that the corresponding levels of the two PPE level classifications are not equivalent due to differences in levels of skin and respiratory protection. outbreak. ${ }^{106}$ Forty-one of them died, most of whom were not wearing appropriate protection and their health system was not prepared for such an emergency. ${ }^{106}$ Remuzzi and Remuzzi reported in their Lancet article that around 20\% of Italy's first-responder HCWs had become infected. ${ }^{106}$ The primary route for the spread of COVID-19 is thought to be through droplets that are expelled during coughing, sneezing, or breathing. ${ }^{59}$ However, there are concerns about possible airborne transmission in healthcare facilities as infection rates among front liners can be as high as $14 \% .{ }^{107}$ Among the strategies for preventing infection among clinicians and HCWs in high-risk patient encounters is the use of the appropriate PPE, specifically N95 and equivalent respirators, goggles or face shields, protective clothing (gowns and aprons), and gloves. In patient encounters and procedures that may induce airborne transmission, the use of more protective respiratory equipment is advocated. ${ }^{29,108}$ This is particularly true for ORL specialists who are always exposed to pathogens in respiratory droplets and aerosols when examining the nasal and oral cavities, and pharynx and larynx, especially when mucosal manipulation is done in both endoscopic and non-endoscopic procedures. This COVID-19 pandemic has already infected more ENT surgeons than other specialists in China and other countries. ${ }^{105,} 109$

\section{Out-patient encounters without any AGP: ORL specialists (and clinic} staff) should wear single-use gloves, a single-use plastic apron, a sessional-use $\mathrm{N} 95$ respirator (or its equivalent), and sessional-use eye and/or face protection (PGH HICU PPE level 2) during a direct patient encounter in the out-patient, ambulatory care setting, with NO intention of performing any AGP.

In the setting of out-patient care and in the context of direct patient care of possible or confirmed cases, the recommended PPE by Public Health England include: single use disposable gloves, single use disposable plastic apron, a fluid-resistant (Type IIR) surgical mask, and eye/face protection for single or sessional use. ${ }^{110}$ However, ENT specialists are advised to use an N95 or equivalent respirator, especially when examining patients with unknown COVID status. ${ }^{28,} 29$ Substitutes and equivalents for N95 respirators include FFP2 respirators (United Kingdom and European market), which have been recommended by the WHO as adequate and effective protection against aerosolized coronavirus particles. ${ }^{111-113}$ Apart from the FFP2, China's KN95, Australia/New Zealand's P2, Korea's 1st Class and Japan's DS FFR respirators are also considered N95equivalent. ${ }^{14,115}$ An N95 respirator and the like should be fit-tested prior to use in the clinics to ensure a tight seal around the face which translates to actual protection from coronavirus contamination. ${ }^{116,117}$ It is important to note that valved N95 substitute or equivalent 


\section{REVIEW ARTICLE}

respirators allow unfiltered air from the wearer to contaminate room air, thus the US CDC recommends their use in the healthcare setting where sterility is not required, such as in outpatient clinic visits and procedures. ${ }^{118}$ Communication issues while wearing respirators have been documented and confirmed by speech intelligibility tests on various respirators, with elastomeric respirators faring poorly compared to $\mathrm{N} 95$ facepiece respirators and PAPRs. In addition, face shields and visors (worn over masks and respirators) can further mitigate sound conduction and communication. However, the impact of the decreased communication on patient care and performance of HCWs have yet to be documented. ${ }^{119}$

Out-patient encounters with an AGP: ORL specialists (and any staff assisting) should always wear single-use gloves, a single-use or reusable protective garment (gown or coverall), a single-use fittested facepiece respirator with more than $95 \%$ filtration efficiency (NIOSH-approved $\mathrm{N} 99$ or its equivalent or a respirator with better filtration efficiency and/or assigned protection factor, or a reusable respirator), and reusable eye and/or face protection (NHS UK PPE Level 2 Airborne Precautions) during a direct patient encounter in the out-patient, ambulatory care setting, with intention of performing one or more aerosol-generating procedures. Consider using a surgical mask or face shield over the facepiece respirator if there is a plan to reuse the latter, or use a reusable respirator instead.

In the setting of out-patient care where the clinician will perform an AGP on possible or confirmed COVID-19 cases, health authorities (such as Public Health England and US health institutions) recommend the single-use of the following PPEs: disposable gloves, a disposable fluid-repellant coverall or gown, a filtering facepiece respirator, and an eye and/or face protection..$^{29,108-110}$ Some AGPs are listed in Table 2. The ENT specialist has the option of using an N95 or equivalent respirator, especially when examining the ears, nose, mouth or throat

Table 2. List of AGPs in ORL-HNS ${ }^{91,121}$

Upper aerodigestive tract examination which include nasal cavities, sinuses, oral cavity, pharynx and larynx.

Outpatient procedures on the upper aerodigestive tract such as endoscopies, nasal cautery, foreign body removal, biopsies and microbiology sampling.

Examination of and interventions on patients with airway modifications such as post-laryngectomy patients.

Management of ORL emergencies such as epistaxis, foreign bodies, complications of acute sinusitis and airway compromise.

Otologic procedures that may also provoke aerosol generation, e.g. aural toilette or suctioning of ears that may induce coughing. of a COVID confirmed, COVID-suspect or asymptomatic patient. ${ }^{29}$ However, the British Association of Oral and Maxillofacial Surgeons and ENT UK consider oral and nasal examination as AGPs and jointly strongly recommend the use of FFP3 respirators (equivalent to $\mathrm{NIOSH}$-approved $\mathrm{N} 99$ respirators with $99 \%$ filtration efficiency) during patient encounters. ${ }^{120}$

Alternatively, reusable respirators may be used by clinicians instead of the disposable facepiece respirators. ${ }^{114}$ These reusable respirators provide better respiratory protection to its wearers (assigned protection factor [APF] ranges between 25 to 1000), compared to the disposable facepiece respirators (APF $=10)$. Among the PPEs, a powered air-purifying respirator (PAPR) can be used for high-risk procedures by a health worker at risk from aerosol or droplet spread. ${ }^{122}$ Otolaryngologists around the world have declared their preference for powered air-purifying respirators (PAPRs) over the use of N95 respirators and face-shields. ${ }^{29,104,123-125}$

Patient (and accompanying person) use of PPE in ORL out-patient clinics: All ORL patients (and accompanying persons) are strongly encouraged to wear a surgical mask during an outpatient visit in an ORL healthcare facility especially if with respiratory symptoms or if they are being evaluated as a case of COVID-19. ORL specialists may require compliance, and consider providing surgical masks for patients (and accompanying persons) wearing only cloth masks before they enter the premises.

In the setting of out-patient care and in the context of direct patient care of possible or confirmed cases, patients (and accompanying persons) are also encouraged to wear face masks during the entire duration of consultation (except during actual trans-nasal and trans-oral examinations) to decrease the risk of transmission. ${ }^{26,29,126}$ Cloth masks are not recommended under any circumstance inside a healthcare facility by the WHO. ${ }^{126}$ Therefore, if possible, the ORL clinic or facility should provide surgical masks for patients who do not have one. It is also important to educate patients and accompanying persons that the use of a surgical mask must be combined with hand hygiene and other infection prevention and control measures, such as proper cough etiquette, to prevent the transmission of SARSCoV- $2 .{ }^{56,126}$

ORL specialists and their staff should practice proper donning and doffing of PPEs, disposal of single-use PPEs, and disinfection and recycling of reusable PPEs.

Proper donning and doffing should be observed prior to and after the out-patient encounter. Various instructional resources are available online, such as the UP-PGH guides to donning and doffing 
level 3 PPEs available from: ${ }^{127}$ http://www.pgh.gov.ph/static/media/ uploads/covid19filesemployees/donning3272020.jpg and from:128 http://www.pgh.gov.ph/static/media/uploads/covid19filesemployees/ doffing3272020.jpg and for level 4 PPEs, available from: ${ }^{129}$ https:// youtu.be/rvq63C5/YNc. The US CDC website on preventing health care infections also provides instructional materials for guidance on effective PPE use (US CDC Protecting Healthcare Personnel) available from: ${ }^{130}$ https://www.cdc.gov/hai/prevent/ppe.html.

Ideally single-use personal protective equipment should be disposed of according to local health code standards. In this regard, the Philippine $\mathrm{DOH}$ has issued a memorandum on the Interim Guidelines on the management of Health Care Waste in Health Facilities with cases of Coronavirus Disease. ${ }^{131}$

In resource-challenged circumstances where re-use of PPE (such as respirators, goggles, face shields) may be necessary, guidelines for acceptable disinfection and recycling of reusable PPEs should be observed. ${ }^{26,125,126}$ In the event of supply shortage during an epidemic or pandemic, reuse of the facepiece respirator is acceptable and recommended by the US CDC. ${ }^{122}$ To reuse a facepiece respirator, a surgical mask or a reusable and cleanable face shield may be worn over it to prevent soiling or contamination of its outer surface; and the user should always observe proper hand hygiene before and after removing the respirator. ${ }^{111-115}$ Several methods or techniques have been suggested by Dr. Peter Tsai, the N95 inventor, on the proper reuse of $\mathrm{N} 95$ and similar respirators. ${ }^{132}$ (Table 3)

Plastic face shields, whether commercially available or improvised

Table 3. Methods of reusing N95 respirators ${ }^{132}$

\begin{tabular}{|l|l|}
\hline Method 1 & $\begin{array}{l}\text { "When reusing N95 masks, leave a used respirator in dry, } \\
\text { atmosphere air for 3-4 days to dry it out. Polypropylene in N95 } \\
\text { masks is hydrophobic, and contains zero moisture. COVID-19 } \\
\text { needs a host to survive--it can survive on a metal surface for } \\
\text { up to } 48 \text { hours, on plastic for } 72 \text { hours, and on cardboard for } 24 \\
\text { hours. When the respirator is dry in 3-4 days, the virus will not } \\
\text { have survived. } \\
\text { Take four N95 masks, and number them (\#1-4). On day 1, use } \\
\text { mask \#1, then let it dry it out for 3-4 days. On day 2, use mask } \\
\text { \#2, then let it dry out for 3-4 days. Same for day 3, and day 4..." }\end{array}$ \\
\hline Method 2 & $\begin{array}{l}\text { "You can also sterilize the N95 mask by hanging it in the oven } \\
\text { (without contacting metal) at 70C (158F) for 30 minutes-it } \\
\text { is reported that COVID-19 cannot survive at 65C (149F) for 30 } \\
\text { minutes. Use a wood clip to hang the respirator in the kitchen } \\
\text { oven to do the sterilization. When sterilizing N95 masks, be wary } \\
\text { of using UV light--keep N95 masks away from UV light / sunlight. } \\
\text { N95 masks are degraded by UV light because it damages the } \\
\text { electrostatic charges in the polypropylene material. It is unclear } \\
\text { how long the masks can be exposed to UV light before they are } \\
\text { ineffective." }\end{array}$ \\
\hline
\end{tabular}

(e.g., 3D printed), may be disinfected using agents included in the list of disinfectants for use for SARS-CoV-2 published by the US EPA. ${ }^{66}$ The U.S. National Institutes of Health 3D Print Exchange recommends soaking of 3D printed parts of improvised face shields in soap and water or $10 \%$ chlorine bleach solution. ${ }^{133}$ Goggles or protective eyewear can also be disinfected using soap and water or chlorine solution as described by the National Science Teaching Association. ${ }^{134}$ "Hazardous Materials" (Hazmat) suits or coveralls, should be decontaminated and reused according to manufacturer's instructions. ${ }^{135}$

Staff engaged in disinfecting and recycling reusable PPE should themselves wear appropriate PPE and observe proper precautions during the entire process, as discussed in our sections on physical office set-up and procedures.

\section{PROCEDURES}

Based on experiences from China, Italy, and Iran, otolaryngologists are among the HCWs with the highest risk of being infected with SARS-CoV-2. ${ }^{136-138}$ This is probably due to close contact with ORL patients, and the high viral density in the nose and nasopharynx, followed by the oropharynx, as well as instrumentation in these areas that may aerosolize virus resulting in increased risk. ${ }^{138}$ The possibility of asymptomatic virus carriage in the nose, ${ }^{139}$ or even in saliva, ${ }^{140}$ and consequently the possibility of asymptomatic transmission, ${ }^{141}$ adds another dimension to the risks that otolaryngologists face.

\section{Consider all ORL out-patients and accompanying persons as COVID-19 positive until proven otherwise.}

Due to stringent testing criteria and limited testing ability of the government, any ORL patient (and accompanying persons) should be considered COVID-19 positive until proven otherwise. ${ }^{142}$ There are multiple reports of asymptomatic carriers and pre-symptomatic transmission. ${ }^{139,143,144}$ Even in patients who have contracted the virus and recovered, there are reports of repeat tests turning out positive - although this may also mean that the initial results postinfection were false negatives, or that the repeat test detected inactive viral particles. ${ }^{13,143,145,146}$ To this end, extra care must be practiced when obtaining the clinical history (including ensuring patients wear at least a surgical mask), and performing procedures that are considered high risk for SARS-CoV-2 infection, particularly endoscopies and routine non-endoscopic examination of the nasal and oral cavities. ${ }^{136,142,147}$ 


\section{REVIEW ARTICLE}

Most otolaryngologic office procedures are potentially AGP and have to be approached with utmost precautions.

An aerosol is defined as a "collection of solid and liquid particles suspended in a gas." ${ }^{148}$ When air flows across the surface of liquid film an aerosol is produced. ${ }^{149}$ Following these definitions, almost all procedures performed by the otolaryngologist, even office-based ones, are potential avenues for aerosol transmission. Coughing and sneezing produce droplets that are aerosolized ${ }^{148}$ while talking, and even breathing produces microdroplets that are also aerosolized. ${ }^{150-152}$ These aerosolized microdroplets may transmit COVID-19.41, 64, 153,154

It is important to note that nasal and laryngeal endoscopies do not inherently produce aerosols, but the associated risk of coughing and sneezing, even the risk of vomiting, classifies these procedures as aerosol-generating. ${ }^{149}$

The other parts of the ORL physical examination such as otoscopy and head and neck palpation may not have as high a risk of aerosolization compared to oral, oropharyngeal, nasal, nasopharyngeal, and laryngeal examinations. However, the risk is still there, as when a cough might be induced by palpating the anterior neck too deeply, or when manipulation in the ear canal might elicit the ear-cough reflex. ${ }^{155,156}$ By virtue of being less than 2 meters away from the patient, otolaryngologists will be at greater risk of infection if the patient inadvertently generates aerosols. ${ }^{157,158}$ This risk is not trivial, as available studies show droplets travel up to 8 meters, and "infections cannot neatly be separated into the dichotomy of droplet versus airborne transmission routes." ${ }^{13}$

Examination of ORL patients should be done in an airborne infection isolation room (AIIR) whenever available. An AlIR should have a negative pressure of $>-2.5 \mathrm{~Pa}(0.01$ " water gauge) and at least $12 \mathrm{ACH}^{60}$ It should also have an ante room for donning and doffing PPEs, a sink for hand hygiene and trash bins for disposing contaminated material.

Examinations should be limited to patients who clearly need them and must be performed by the least number of the most experienced personnel available in an expedient way. The PPE used should be appropriate to the risk attending the specific procedure, as detailed in our subsection on personal protection.

\section{A focused or directed ORL physical examination may be considered in the setting of the current COVID-19 pandemic.}

Ideally, the full ORL physical examination must be performed to ensure excellent quality care for our patients. However, it is left to the individual clinician to determine and discuss the risks and benefits of a focused ENT physical examination with their respective patients, in the setting of the current COVID-19 pandemic and the immediate
"post'-COVID-19 period before a vaccine is developed and herd immunity has been achieved. Things that must be considered include, but are not limited to, obtaining informed consent, clinical suspicion of COVID status, availability of appropriate PPE, judicious and careful use (and disposal or disinfection for reuse) of aural and nasal specula, cheek retractors, tongue depressors, mirrors, otoscopes, endoscopes, and video systems. Hybrid systems incorporating telemedicine tools (for pre-accomplishing clinical information, initial history-taking, and even physical inspection) as well as camera-based physical examinations (that increase the distance between patient and examiner) may also be considered. ${ }^{138,147,159}$

Ear cleaning (cerumen extraction by curette, syringing, suctioning), wick insertion for otitis externa, are potential aerosol - generating procedures, and appropriate precautions must be observed.

Cerumen extraction is a common out-patient office procedure for many ORL specialists, and curette-extraction or syringing can both induce a cough reflex. ${ }^{160}$ Even insertion of an ear wick for better delivery of otic medications in the setting of acute otitis externa may stimulate the ear-cough reflex. ${ }^{155,156,160}$ When performing these procedures, the appropriate PPE should be donned by the physician (and any assisting staff) and the patient should maintain a surgical mask (at least), preferably covered by a face shield (see section on personal protection).

\section{Ear canal foreign bodies may also require emergent or urgent office} intervention in the setting of retained button batteries, animate foreign bodies, or obstructive otitis externa.

A retained button battery in the external auditory canal should be treated emergently with appropriate PPE if any office intervention is to be considered. Animate foreign bodies (e.g., insects, etc.) or other foreign bodies with a marked inflammatory reaction causing obstructive otitis externa also require operative intervention. If the child (or other patient) is unable to tolerate the procedure awake, conscious sedation may be preferred to general anesthesia, which requires positive pressure ventilation. ${ }^{161}$ As such, this may cease to be an out-patient procedure and require ambulatory hospital care.

\section{Middle ear procedures should be performed only for ABSOLUTE indications with complete PPE.}

Respiratory viral pathogens (rhinovirus, respiratory syncytial virus, coronavirus) have been found in the middle ear during episodes of acute otitis media. ${ }^{162}$ While SARS-CoV-2 has not been specifically identified, it may be reasonable to assume that it may also be found in the middle ear. This is the context wherein the clinician may be 
exposed to the virus when suctioning the middle ear and performing aural toilette for otitis media.

The use of non-fenestrated microsuction is recommended for ear procedures.

Significant aerosolization of biological materials may occur during ear microsuctioning, particularly with fenestrated suction. Although the risk of COVID-19 transmission with microsuction is low particularly for wax clearance in the absence of inflammation, the use of non-fenestrated suction tips probably reduces the risk of aerosolization. ${ }^{163}$

Myringotomy with or without tympanostomy tube insertion should only be performed for urgent and emergent conditions.

The same applies during myringotomy with or without tympanostomy tube insertion. The AAO-HNS ${ }^{161,164}$ has recommended performing these procedures only for urgent or emergent conditions (e.g., complicated acute otitis media) with the patient under general anesthesia with endotracheal intubation. However, Philippine otolaryngologists may opt to perform outpatient myringotomy with or without tympanostomy tube insertion under local or topical anesthesia. In such cases, it is strongly recommended that the same PPE requirements as previously discussed in the preceding sections of this document be applied. The patient should also be wearing a surgical mask while undergoing the procedure.

For patients with unknown, suspected, or positive COVID-19 status, myringotomy and tympanostomy tube insertion is preferred to cortical mastoidectomy for uncomplicated acute mastoditis refractory to medical therapy, as the risk of exposure is less. ${ }^{161}$

Non-endoscopic routine examination of the nasal cavity, oral cavity, and the naso-, oro-, and hypopharynx are high-risk AGPS and should only be performed if ABSOLUTELY necessary.

Routine examination of these mucosa-lined structures are considered high-risk AGPs and must be avoided unless an absolute indication exists (e.g., retained foreign body, intractable bleeding, etc.). ${ }^{136,138,142}$

When absolutely indicated, it is recommended that as much as possible, these procedures be performed in a negative-pressure room, the ENT surgeon wears complete PPE, and the use of barriers and endoscopes with camera systems are employed to mitigate the risks of aerosolization and infection. A detailed discussion on negative-pressure rooms, HEPA filters and PPE are in other sections of this review.
Epistaxis should initially be managed in the out-patient setting as conservatively as possible with digital nasal pressure and medications, while ensuring the safety of patients and staff.

Patients presenting with epistaxis should be treated in the outpatient setting by applying digital nasal pressure for 15 minutes, administering tranexamic acid, and control of risk factors (blood pressure, aspirin, anticoagulants) and insertion of a nasal pack. ${ }^{165,166}$ Routine anterior rhinoscopy and endoscopy, applying topical decongestants and suctioning may have to give way to "blind" outpatient epistaxis management, especially when the physician and patient are not adequately protected by PPE, and/or when the ideal situation - transfer to a nearby hospital Emergency Room - is not feasible or possible.

The highest possible score should be assigned for tonsillar inflammation physical finding scoring systems in children with a clinical history consistent with streptococcal pharyngitis. Adults presenting as acute tonsillopharyngitis should be treated by history alone without an examination of the mouth and throat unless airway compromise or sepsis is suspected.

A guideline from the Royal College of Paediatrics and Child Health and the British Paediatric Allergy Immunity and Infection Group ${ }^{167}$ recommends assigning the highest possible score for tonsillar inflammation physical finding scoring systems in children $>3$ years of age complaining of sore throat and a history consistent with streptococcal pharyngitis. This is to decrease the risk of infection of the ENT surgeon and to conserve scarce PPE. ${ }^{167}$ While this recommendation was used for children using the FeverPAIN Clinical scoring system, ${ }^{168}$ it may reasonably be extrapolated to adults when using the M-CENTOR scoring system for streptococcal pharyngitis. ${ }^{169}$ However, the ENT UK COVID-19 tonsillitis and quinsy guidelines recommend that adults presenting as acute tonsillopharyngitis should be treated by history alone if possible, and without an examination of the mouth and throat unless airway compromise or sepsis is suspected. ${ }^{170}$

Moreover, it should be reiterated that patients complaining of fever and sore throat should be managed as a suspect case of COVID-19, and referred to the government-mandated screening process.

Nasal and laryngeal endoscopies should only be performed for ABSOLUTE indications and with complete PPE for AGPs.

Absolute indications include those that are necessary to prevent morbidity or mortality in the next 30 days, ${ }^{138}$ e.g., airway obstruction, 


\section{REVIEW ARTICLE}

Philippine Journal Of Otolaryngology-Head And Neck Surgery

Vol. 35 No. 1 January - June 2020

malignancy, foreign body, persistent epistaxis. Complete PPE for AGP entails an N99 or N100 mask (or N95 mask with a 3-ply surgical mask over it), or use of a powered air-purifying respirator (PAPR) if available, surgical cap, goggles and face shield, waterproof gown, gloves, and shoe covers or booties. ${ }^{138,142,171}$

Flexible fiberoptic endoscopies using the smallest diameter scope are preferred over rigid endoscopes, and the use of a video monitor is recommended to increase the distance between the physician's face and the patient. ${ }^{138}$ Alternatives to laryngoscopy should be considered (e.g. CT scanning, laryngeal ultrasound, etc.) for other cases such as work-ups of head and neck masses, lymphadenopathy and mild airway stenosis. ${ }^{172}$

\section{Decongestants and anesthetics should be applied with cottonoid strips or instilled by drops or gel and should not be sprayed.}

Topical decongestants with anesthesia (1:100,000 epinephrine $+2 \%$ lidocaine carpules; or oxymetazoline $0.05 \%$ adult spray / $0.025 \%$ pediatric solution plus $2 \%$ lidocaine) should be applied with cottonoid strips or instilled in drops or gel form to blunt the cough and sneeze reflexes. These should NOT be sprayed to lessen the risk of aerosolizing the virus.

\section{Barrier methods may be employed during endoscopies to reduce the risk of droplet transmission and infection.}

Multiple methods of creating a barrier between the patient (and the patient's possible secretions) and the physician are in varying stages of development, and may be found in traditional (e.g., published literature) and non-traditional sources of scientific information (e.g., social media).

Adapting the aerosol box ${ }^{173,174}$ for outpatient procedures may be considered in addition to complete PPE precautions as another strategy to decrease contamination and risk of spreading the aerosolized virus. A plastic sheet draped over a PVC frame originally intended for intubations and patient transport may also be adapted for outpatient procedures. ${ }^{175,176}$ A study by Workman et al. using cadavers and atomizers showed that the use of surgical masks and valved endoscopy of the nose and throat (VENT) masks prevent the spread of aerosols during simulated sneezing. ${ }^{149}$ Figure 4 shows VENT modification with a double one-way valve similar to a double septum secundum by our co-author Dr. Ryner Jose C. Carrillo. Another example is an innovation where otolaryngologists in Thailand used seats and hair dryers in salons, a pacifier and a plastic film to create a barrier between the patient and the examiner that still enabled endoscopic examination. ${ }^{177}$

The Zamboanga City Medical Center Department of ORL-HNS under our co-author Dr. Justin Elfred Lan B. Paber has developed

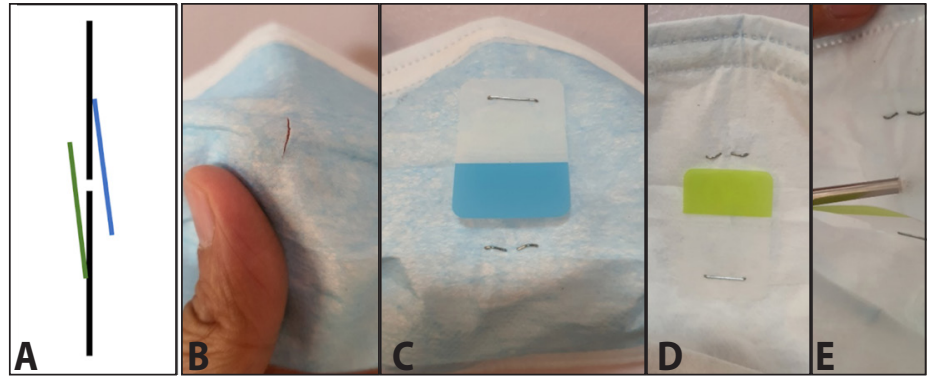

Figure 4. Surgical mask with endoscopy valve. A. Modification of the valved endoscopy of the nose and throat (VENT) mask: ${ }^{149}$ A double one-way valve is fabricated (like a double septum secundum). B. A vertical cut in the upper mid portion of the mask is made, creating a slit 2.5 to $10 \mathrm{~mm}$ in height depending on the intended scope or instrument to be inserted. One or two valves can be created. C. Plastic flaps are stapled superior to the hole in front of the mask. D. inferior to the hole behind the mask. The flaps cover the hole and minimize droplets and aerosols from entering and exiting. Taping the mask to the patient's face and chin is an option for added seal. E. The scope can enter the valve with the mask acting as an aerosol shield.
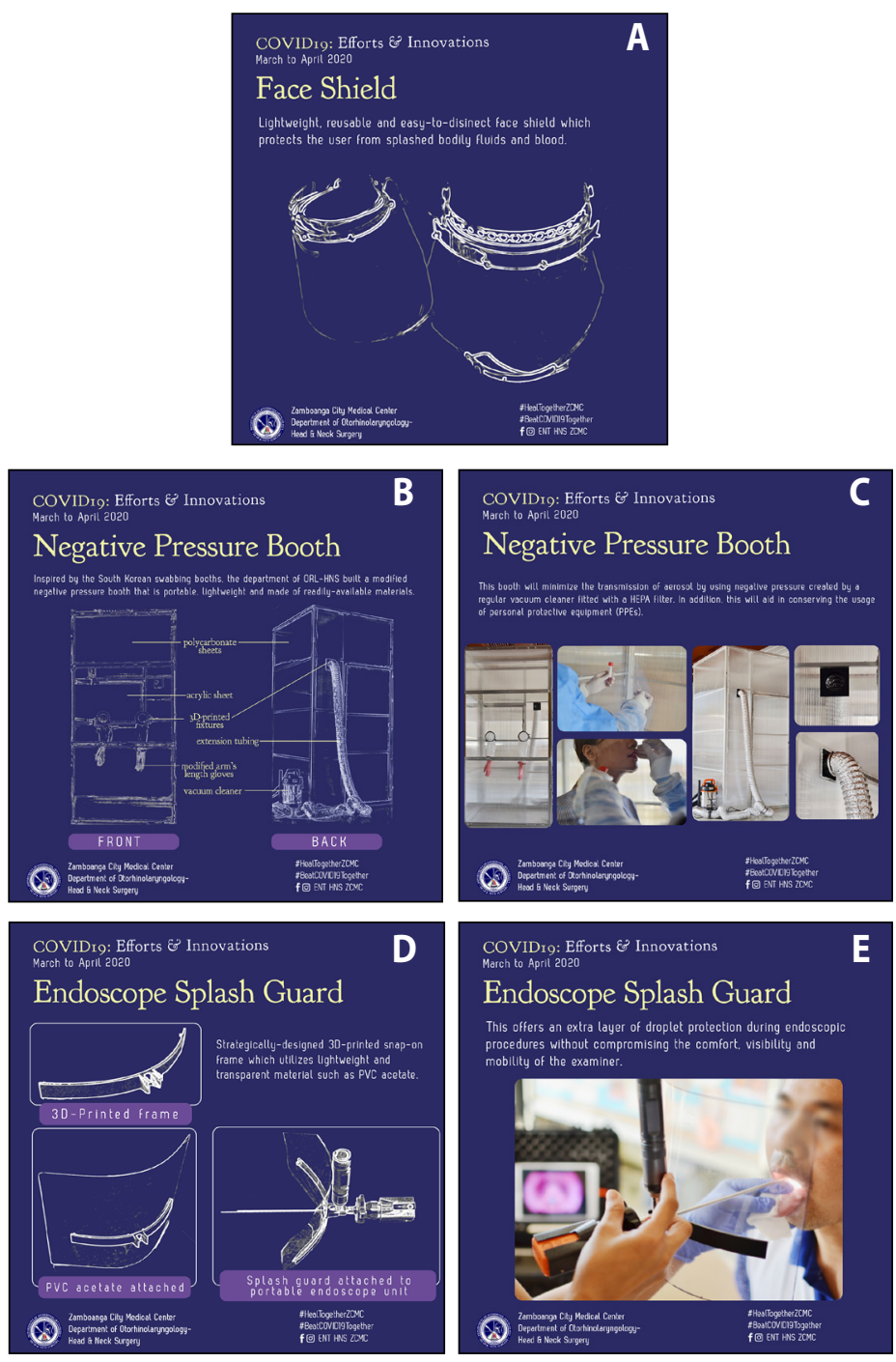

Figure 5. COVID-19: Efforts \& Innovations of Zamboanga City Medical Center Department of ORL-HNS: A. 3D printed frame for a DIY face shield; B., C. Makeshift negative pressure booth; D., E. Endoscope splash guard. (Photos published with permission) 

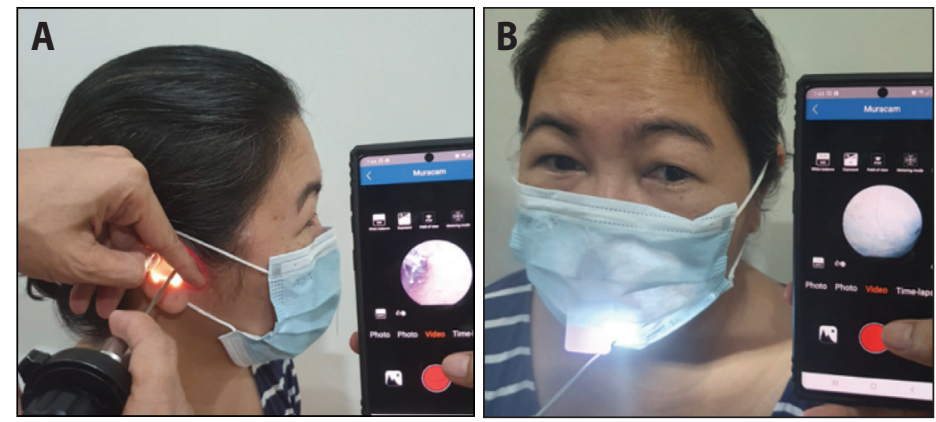

Figure 6. Camera-based ENT examination. A. Otoscopy using a scope attached to a camera. B. Oral, nasal, laryngeal examination may be performed through a hole in the mask. Removal of oropharyngeal foreign bodies (not shown), may be facilitated by creating another hole in the mask to introduce a forceps. (Photos published in full, with permission)

portable endoscope splash guards from acetate and 3D-printed frames, as well as makeshift examination booths with negative pressure. ${ }^{62}$ (Figure 5)

\section{Camera-based procedures increase physical distance and may decrease exposure.}

Camera-based ear, nose and oral cavity examination and laryngoscopy may increase the distance between patient and examiner, and possibly lessen exposure to infectious material. (Figure 6) A $2.7 \mathrm{~mm}$ Hopkins scope mounted on a portable camera can be used for otoscopy, oral and nasal examination while the patient is wearing a surgical mask. The scope is passed through small puncture holes in the mask. Nasopharyngeal and laryngeal endoscopy are optional using flexible or rigid scopes. The patient is asked to pull out their tongue and an additional puncture is placed in the mask if needed for access (e.g., for forceps during extraction of readily accessible foreign bodies such as fish bone embedded in the tonsil or tonsillar pillar). This set-up may lessen aerosolization while performing routine simple examinations, with the face of the patient covered all throughout the procedure. Foreign bodies located deeper in the oro- and hypopharyngeal areas may require an operating room set-up. ${ }^{149,172}$ Observance of proper PPE donning and doffing with a trained observer is still recommended for all these high risk procedures, regardless of the presence of a physical barrier.

The standard practice of using FDA-approved chemicals for instrument disinfection and sterilization, per recommendations of CDC disinfection guidelines, can be applied to eradicate the presence of coronavirus in medical equipment.

Standard instrument disinfection applies as recommended by the US CDC Guideline for disinfection and sterilization in healthcare facilities. ${ }^{178} \quad$ Varying degrees of minor outpatient procedures utilizing facilities and instruments will require different levels of housekeeping. Accessible and affordable cleaning materials should be used for sustainable outpatient service or office-based procedures. Some US FDA recommended instrument sterilants or disinfectants that are readily available for Philippine use include: High level disinfectants such as $2.4 \%$ glutaraldehyde (Cidex ${ }^{\circledast}$ ) which can be used for a 45 minute soak with the solution reusable for 14 days; and $3.4 \%$ glutaraldehyde (Cidexplus ${ }^{\circledR}$ ) which can be used for a 20 minute soak with the solution reusable for 28 days. ${ }^{68}$ Readily accessible hand and instrument surface disinfectants consisting of alcohol-based solutions range from $70 \%$ isopropyl or ethyl alcohol to propanol-based solutions (Cutasept ${ }^{\circledR}$ and Sterillium ${ }^{\circledR}$ ). Other methods of sterilization include autoclaving and ultraviolet light type C. ${ }^{71,179}$ Caution is advised with using ultraviolet light as this may injure skin and eyes.

Strict observance of proper PPE use (see section on personal protection) must be followed while performing disinfection procedures. It is also recommended to use an isolation screen while performing reprocessing, involving the minimum number of highly trained staff. ${ }^{178}$

\section{PREVENTION AND HEALTH PROMOTION}

A balanced diet, appropriate exercise, and adequate rest are essential to wellness, disease-prevention, and health promotion. While no vaccines or cures for COVID-19 yet exist, there is insufficient or no evidence for the use of topical solutions, vitamins, supplements, antibiotics, antimalarials or vaccines as prophylaxis for or prevention of COVID-19.

Good health and a healthy lifestyle help prevent illness, while poor health and an unhealthy lifestyle predispose people to various diseases including chronic lifestyle-diseases, infections, and neoplasms..$^{90,101-103,180}$ These maxims are not any different as far as the COVID-19 pandemic is concerned. Conventional wisdom and numerous studies support a well-balanced diet, appropriate exercise and adequate rest as essential to wellness, disease-prevention and health promotion. ${ }^{181,182}$ Aside from healthy diet, exercise and rest, disease-prevention and health promotion may involve such strategies as decreasing viral load, or increasing host immunity.

There is currently no clear evidence for the use of topical preparations of povidone iodine, saline solution, vitamin $C$, or Virgin Coconut Oil (VCO), in decreasing viral load in COVID-19.

Povidone iodine solution has been proposed to potentially decrease viral load. Studies by Eggers and Kariwa show the lowest concentration of povidone-iodine to be effective in vitro was $0.23 \%$, 


\section{REVIEW ARTICLE}

leading to reduction of viral activity to undetectable levels. ${ }^{183,}{ }^{184} \mathrm{~A}$ recent study by Kampf et al. showed that SARS-CoV-2 should behave similarly. ${ }^{185}$ A $1 \%$ povidone iodine solution is locally available and is marketed to be used as $15 \mathrm{~mL}$ to be gargled for 30 seconds, repeated 2 to 4 times daily. Another locally available solution is marketed as a $0.45 \%$ throat spray, to be used 3-4 times daily. ${ }^{186}$ Mady et al. proposed the use of povidone-iodine as a form of personal protection for HCWs, with the following dilution, mode of delivery, and dosing: ${ }^{187}$

a. Nasal irrigation: $240 \mathrm{~mL}$ of $0.4 \%$ PVP-I solution (dilution of 10 $\mathrm{mL}$ of commercially available $10 \%$ aqueous PVP-I in $240 \mathrm{~mL}$ of normal saline with a sinus rinse delivery bottle); and

b. Oral/oropharyngeal wash: $10 \mathrm{~mL}$ of $0.5 \%$ aqueous PVP-I solution (1:20 dilution in sterile or distilled water).

They proposed that healthcare providers apply the nasal and oral PVP-I before and after each patient contact (or every 2-3 hours, up to $4 \times /$ day for repeated patient contact). However, there is no evidence that this actually decreases viral load in COVID-19.

An experimental sodium chloride - sodium bicarbonate buffered solution with $1.5 \mathrm{mg} / \mathrm{ml}$ sodium ascorbate has been proposed for intranasal (1-3 drops per nostril) and transoral (4-6 drops on tongue) prophylaxis (every 4-6 hours) by retired Professor Gisela Concepcion of UP in collaboration with other ORL specialists. ${ }^{188}$ Saline solution has long been used for nasal douches and oral gargles with most preparations using a range between hypertonic $(3 \%)$ to isotonic $(0.9 \%)$ and hypotonic $(0.65 \%)$ sodium chloride and has been associated with reduction in microbial antigens and a related decline of microbial burden. ${ }^{189,190}$ In particular, saline inhibits RNA viral replication ${ }^{191,192}$ and hypertonic saline denatures viral structures, preventing viral replication and synthesis ${ }^{193}$ although it may affect mucociliary flow. ${ }^{194}$ Because vitamin $C$ has been claimed to inactivate influenza viruses (in an animal study) ${ }^{195}$ and because it has long been advocated as a remedy for colds and influenza, it might hypothetically exert protective effects when applied directly to nasal mucosa in combination with saline solution. ${ }^{196-198}$ As this combination was developed during the present COVID-19 pandemic, no formal studies have been conducted, and no therapeutic claims are made for its use.

Virgin coconut oil has also been proposed as prophylaxis against SARS-CoV-2 because VCO and lauric acid derivatives have in-vitro antiviral effects, possibly through destroying virus envelopes, inhibiting late stage virus maturation, and preventing the binding of the viral proteins to the host's cell membranes. ${ }^{199,}{ }^{200}$ Although people have anecdotally applied VCO topically in their nostrils and swished it in their mouths as topical prophylaxis (instead of ingesting it) to inhibit SARS-CoV-2 particles, there is currently no evidence to support this practice, or the use of VCO in the adjunctive treatment of COVID-19. ${ }^{201}$

\section{There is insufficient evidence for the use of oral supplements like vitamin $C$ and $D$, zinc, and melatonin as prophylactics against COVID-19.}

There are relatively low risk, oral prophylactic supplements currently being advertised such as thiamine, vitamins $C$ and $D$, zinc $^{202,203}$ and melatonin. ${ }^{204}$ Although Rapid Evidence Reviews of the UP Institute of Clinical Epidemiology and Asia-Pacific Center for Evidence-Based Healthcare found "no direct evidence available ... for efficacy of intravenous vitamin $C$ as an adjunctive treatment in preventing mortality or shortening disease course among adults with COVID-19,"205 vitamin C has long been used to prevent the common cold and as a cold and flu remedy, and has shown a "possible increased benefit in patients subjected to cold stress." 198,206

Zinc "may possess a protective effect" against SARS-CoV-2 and be used as a supplement for "preventive ... therapy of COVID-19" by "reducing inflammation," improving "mucociliary clearance," and modulating "antiviral and antibacterial immunity." ${ }^{207}$ Although there are two ongoing clinical trials investigating zinc supplements combined with other medications as prevention for COVID-19, there is currently "no clinical evidence that zinc supplementation should be used for the prevention of COVID-19."208

A pre-print reporting that the mean level of vitamin $D$ in each of 20 European countries was strongly associated with the number of cases/1M and with the mortality/1M, and was especially low in Spain, Italy, and Switzerland advises Vitamin D supplementation to protect against SARS-CoV2 infection. ${ }^{209}$ Vitamin D3 supplementation at 10,000 IU/day was also recommended by Grant et al., although this recommendation was based on indirect evidence, observational, and ecological studies only. ${ }^{182}$

Melatonin shows anti-inflammatory and antioxidant properties in vitro and may have an indirect antiviral effect, but because "there are no published clinical trials nor ongoing trials found," there is currently "no sufficient evidence to support" its "use as prophylaxis for COVID-19." 210

While each of these oral supplements may have its own relative merits, there is no sufficient evidence for their actual benefit vis-avis the novel coronavirus. Thus, we recommend prudence in utilizing any of these for prevention, prophylaxis or as immune boosters, particularly cautioning against mega-dosing and the complications that ensue from such practices. ${ }^{211-21}$ 
There is currently no evidence to support the use of chloroquine or hydroxychloroquine (HCQ), with or without azithromycin as chemoprophylaxis against COVID-19.

There is much debate and controversy on the use of various antimicrobials for the treatment of SARS-CoV-2, more so for their use as prophylactics. ${ }^{214}$ In particular, the widespread use of HCQ was propounded by US President Donald Trump, ${ }^{215}$ used alone or in combination with Azithromycin. ${ }^{216}$ However, subsequent reports of serious complications, including several deaths ${ }^{217}$ resulted in warnings being issued by such agencies as the WHO and Philippine $\mathrm{DOH}$ and Philippine Society for Microbiology and Infectious Diseases (PSMID). ${ }^{218,219}$ There is currently no evidence to support chemoprophylaxis using chloroquine or HCQ against COVID-19. ${ }^{219}$ Moreover, there is no high-quality evidence proving the efficacy and safety of HCQ with azithromycin for the treatment of COVID-19.220

There is insufficient evidence for the use of the Bacillus CalmetteGuerin (BCG) vaccine as prophylaxis for COVID-19, but clinical trials are ongoing to determine its efficacy and safety in preventing COVID-19 and its severe symptoms. The US CDC has issued guidelines for prophylactic use of seasonal influenza vaccine in special settings.

The BCG vaccine has been getting attention for its possible immunomodulatory effects, primarily through the innate immune system, as prophylaxis for COVID-19.221 Current evidence does not support this at present ${ }^{222,223}$ but five clinical trials are underway among HCWs to determine the efficacy and safety of BCG vaccine in preventing COVID-19 and its severe symptoms. ${ }^{223,224}$ Meanwhile, the US CDC has guidelines for prophylactic seasonal influenza vaccine use in long-term care facilities, and while the influenza vaccine is not effective against COVID-19 virus, it is highly recommended for vulnerable persons to get vaccinated each year to prevent seasonal influenza infection. ${ }^{225 ; 226}$

Only an effective vaccine against the SARS-CoV-2 will be the gold standard for prophylaxis against COVID-19. Until such time that one is available, all persons encountered should be considered as potentially COVID-19 positive.

Ultimately, an effective vaccine against the novel coronavirus would be the gold standard for prophylaxis if and when one should finally be developed. To date, there are several vaccines at various stages of development around the world. ${ }^{227}, 228$ A COVID-19 Vaccine \& Therapeutics Tracker with the latest updates for vaccine and therapeutic drug developments for COVID-19 is available from:229 https://biorender.com/covid-vaccine-tracker?utm_campaign $=$ Vaccine + Tracker\%3A+Announce\&utm_content $=$ COVID-19+Vaccin e+Tracker\%3A+Announcement\&utm_medium=email_action\&utm_ source=customer.io In the meantime, until such time that one is available (or until widespread herd immunity has been achieved), all persons encountered should be considered as potentially COVID-19 positive.

Peer support is necessary to ensure wellness among HCWs and enable them to provide high quality care.

As the "response to the COVID-19 pandemic is a marathon, not a sprint ... planning should begin for a longer, disillusionment phase during which emotional needs among HCWs will grow."230 Peer support at institutional or organizational levels should "provide leadership focused on resilience," "structure crisis communications to provide information and empowerment," and "create a continuum of staff support within the organization."230

The Johns Hopkins 24/7 "confidential peer support program ... Resilience in Stressful Events (RISE)..." provides in-person psychological first aid and emotional support to HCWs. ${ }^{230}$ The American Medical Association (AMA) has a "free program" PeerRXMed (PeerRx) "that uses a 'buddy system' to provide support and guidance for physicians and other health professionals."231 The American College of Physicians (ACP) encourages "sharing challenges and successes" to "help meet urgent needs during the evolving pandemic" through its "Physician Well-Being and Discussion Forum"232 while the AAO-HNS has a special podcast on "Managing Your Wellness."233 Closer to home, Rappler.com provides "a list of institutions and organizations offering free online counseling for people affected by the coronavirus pandemic."234

\section{PRACTICE IMPLICATIONS}

The bottom-line question we asked ourselves as co-authors as well as our reviewers was: "would you (and could you) implement these recommendations in your practice?" A unanimous "yes" is the answer of all co-authors and reviewers representing diverse practice settings in different classes of provinces, cities and municipalities from various geographic regions in the Philippines. We believe these recommendations are consistent with the best available evidence to date, and are globally acceptable while being locally applicable.

We particularly address the concerns of ORL specialists, HNS, and facial plastic and craniomaxillofacial surgeons about resuming their out-patient clinical office practices during the "post"-COVID-19 period when strict quarantines are gradually lifted and a transition to the 
"new" normal is made despite the unavailability of a specific vaccine for SARS-CoV-2. While these specifically target practice settings in the Philippines, we believe they will be useful to our colleagues in other countries as well.

Our recommendations cover the range of office practice, from physical office set-up to processing of patients, through personal protection and procedures, to prevention, prophylaxis and health promotion. We hope that they will be as helpful, relevant and practical for you as they are for us and that we all will be able to ensure a balance between service and safety as we continue to serve our patients during these challenging times.

\section{REFERENCES}

1. World Health Organization (WHO). Coronavirus disease 2019 (COVID-19) Situation Report 51. Data as reported by national authorities by 10AM CET 11 March 2020 [Cited 2020 April 11]. Available from: https://www.who.int/docs/default-source/coronaviruse/situationreports/20200311-sitrep-51-covid-19.pdf

2. Zhu N, Zhang D, Wang W, Li X, Yang B, Song J, et al., China Novel Coronavirus Investigating and Research Team. A novel coronavirus from patients with pneumonia in China, 2019. NEngl J Med 2020 Feb 20;382(8):727-733. DOI:10.1056/NEJMoa2001017. PubMed PMID:31978945; PubMed Central PMCID: PMC7092803.

3. Zhou P, Yang XL, Wang XG, Hu B, Zhang L, Zhang W, et al. A pneumonia outbreak associated with a new coronavirus of probable bat origin. Nature. 2020 Mar;579(7798):270-273. DOI 10.1038/s41586-020-2012-7. PubMed PMID:32015507 PubMed Central PMCID: PMC7095418.

4. Li Q, Guan X, Wu P, Wang X, Zhou L, Tong Y, et al. Early Transmission Dynamics in Wuhan, China, of Novel Coronavirus-Infected Pneumonia. N Engl J Med. 2020 Mar 26;382(13):11991207. DOI:10.1056/NEJMoa2001316. PubMed PMID: 31995857; PubMed Central PMCID: PMC7121484.

5. Yeager A. Coronavirus's genetics hint at its cryptic spread in communities - Contact tracing and genetic testing reveal how SARS-CoV-2 circulated among individuals for weeks, especially in the US, before being detected. The Scientist, 2020 Mar 6 [Cited 2020 April 12]. Available from: https://www.the-scientist.com/news-opinion/coronaviruss-genetics-hint-at-its-crypticspread-in-communities-67233

6. Johns Hopkins Resource Center. Johns Hopkins Coronavirus Resource Center [Internet] COVID-19 Dashboard by the Center for Systems Science and Engineering (CSSE) at Johns Hopkins University (JHU). 2020 [cited 2020 Apr 15]. Available from: https://coronavirus.jhu edu/map.html

7. Wu Z, McGoogan JM. Characteristics of and Important Lessons from the Coronavirus Disease 2019 (COVID-19) Outbreak in China: Summary of a Report of 72314 Cases From the Chinese Center for Disease Control and Prevention. JAMA. 2020 Feb 24;323(13):1239-1242. DOI: 10.1001/jama.2020.2648. PubMed PMID: 32091533

8. Wilder-Smith A, Freedman DO. Isolation, quarantine, social distancing and community containment: pivotal role for old-style public health measures in the novel coronavirus (2019nCoV) outbreak. J Travel Med. 2020 Mar 13;27(2). pii: taaa020. DOl: 10.1093/jtm/taaa020. PubMed PMID: 32052841; PubMed Central PMCID: PMC7107565.

9. Thanh Le T, Andreadakis Z, Kumar A, Gómez Román R, Tollefsen S, Saville M, Mayhew S. The COVID-19 vaccine development landscape. Nat Rev Drug Discov. 2020 May; 19(5):305-306. DOI: 10.1038/d41573-020-00073-5. PubMed PMID: 32273591.

10. Ahn D-G, Shin H-J, Kim M-H, Lee S, Kim H-S, Myoung J, et al. Current Status of Epidemiology, Diagnosis, Therapeutics, and Vaccines for Novel Coronavirus Disease 2019 (COVID-19). Microbiol Biotechnol. 2020 Mar 28;30(3):313-24. DOI: 10.4014/jmb.2003.03011. PubMed PMID: 32238757.

11. Godin M. Sweden's Relaxed Approach to the Coronavirus Could Already Be Backfiring Time. 2020 Apr 9 [Cited 2020 April 21]. Available from: https://time.com/5817412/swedencoronavirus/

12. Meyerowitz-Katz G. Here's Why Herd Immunity Won't Save Us from the COVID-19 Pandemic Science Alert. 2020 March 30 [Cited 2020 Apr 22]. Available from: https://www.sciencealert. com/why-herd-immunity-will-not-save-us-from-the-covid-19-pandemic

13. An J, Liao X Xiao T Qian S, Yuan J, Ye H et al Clinical characteristics of the recovered COVID-19 patients with re-detectable positive RNA test. (Preprint) medRxiv DOI: https://doi.org/10.1101 /2020.03.26.20044222. [Cited 2020 April 20]. Available from: https://www.medrxiv.org/conte $\mathrm{nt} / 10.1101 / 2020.03 .26 .20044222 \mathrm{v} 1$

14. Leung H. Can You Be Re-Infected After Recovering From Coronavirus? Here's What We Know About COVID-19 Immunity. Time. 2020 April 3, 2020; Updated 2020 April 13 [Cited 2020 April 20]. Available from: https://time.com/5810454/coronavirus-immunity-reinfection/

15. Hancocks $P$, Seo $Y$, Hollingsworth J. Recovered coronavirus patients are testing positive again. Can you get reinfected? CNN Health. 2020 April 18 [Cited 2020 April 20]. Available from: https://edition.cnn.com/2020/04/17/health/south-korea-coronavirus-retesting positive-intl-hnk/index.htm

16. Xia J, Tong J, Liu M, Shen Y, Guo D. Evaluation of coronavirus in tears and conjunctival secretions of patients with SARS-CoV-2 infection. J Med Virol. 2020 Feb 26;92(6):589-594. DOI:10.1002/jmv.25725. PubMed PMID: 32100876.

17. Li JO, Lam DSC, Chen Y, Ting DSW. Novel Coronavirus disease 2019 (COVID-19): The importance of recognising possible early ocular manifestation and using protective eyewear. Br J Ophthalmol. 2020 Mar;104(3):297-8. DOI: 10.1136/bjophthalmol-2020-315994. PubMed PMID: 32086236.

18. Xu R, Cui B, Duan X, Zhang P, Zhou X, Yuan Q. Saliva: potential diagnostic value and transmission of 2019-nCoV. Int J Oral Sci. 2020 Apr 17;12(1): 11. DOI: 10.1038/s41368-0200080-z. PubMed PMID: 32300101; PubMed Central PMCID: PMC7162686.

19. Wang W, Xu Y, Gao R, Lu R, Han K, Wu G, Tan W. Detection of SARS-CoV-2 in Different Types of Clinical Specimens. JAMA. 2020 Mar 11. DOI: 10.1001/jama.2020.3786. [Epub ahead of print] PubMed PMID: 32159775; PubMed Central PMCID: PMC7066521.

20. Xu K, Lai X, Liu Z. Suggestions on the prevention of COVID-19 for health care workers in department of otorhinolaryngology head and neck surgery. World J Otorhinolaryngol Head Neck Surg. 2020 Apr 2. DOI: 10.1016/j.wjorl.2020.03.002. PubMed PMID: 32292630; PubMed Central PMCID: PMC7128200.

21. Medema G, Heijnen L, Elsinga G, Italiaander R, Brouwer A. Presence of SARS- Coronavirus-2 in sewage, medRIX. 2020 Mar 30 [cited 2020 April 6]. Available from: https://www.medrxiv.org/ content/10.1101/2020.03.29.20045880v1. DOl: 10.1101/2020.03.29.20045880.

22. World Health Organization (WHO) [Internet]. Scientific Brief: Modes of transmission of 
virus causing COVID-19: implications for IPC precaution recommendations. 2020 March 29 [Cited 2020 April 21]. Available from: https://www.who.int/news-room/commentaries/ detail/modes-of-transmission-of-virus-causing-covid-19-implications-for-ipc-precautionrecommendations

23. Lewis D. Is the coronavirus airborne? Experts can't agree. Nature. 2020 April 9;580(7802):175 [Cited 2020 April 22]. Available from: https://www.nature.com/articles/d41586-020-00974-w DOI: 10.1038/d41586-020-00974-w. PMID: 32242113.

24. American Academy of Otolaryngology - Head and Neck Surgery (AAO-HNS). Position Statement: Otolaryngologists and the COVID-19 Pandemic. March 23, 2020 [Cited 2020 April 12]. Available from: https://www.entnet.org/content/otolaryngologists-and-covid-19pandemic

25 Chan JYK, Wong EWY, Lam W. Practical Aspects of Otolaryngologic Clinical Services During the 2019 Novel Coronavirus Epidemic: An Experience in Hong Kong. JAMA Otolaryngol Head Neck Surg. 2020 Mar 20. DOI: 10.1001/jamaoto.2020.0488. PubMed PMID: 32196070.

26. Centers for Medicare \& Medicaid Services (CMS) Recommendations: Re-opening Facilities to Provide Non-emergent Non-COVID-19 Healthcare: Phase I. 2020 April 19. [Cited 2020 April 22]. Available from: https://www.cms.gov/files/document/covid-flexibility-reopen-essentialnon-covid-services.pdf

27. American College of Surgeons (ACS): COVID-19 Guidelines for Triage of Otolaryngology Patients. 2020 Mar 24 [Cited 2020 April 22]. Available from: https://www.facs.org/covid-19/ clinical-guidance/elective-case/otolaryngology

28. The Royal College of Surgeons: Guidance for ENT during the COVID-19 pandemic. $2020 \mathrm{Mar}$ 16 [Cited 2020 April 22]. Available from: https://www.entuk.org/guidance-ent-during-covid19-pandemic

29. Givi B, Schiff BA, Chinn SB, Clayburgh D, lyer NG, Jalisi S, et al. Safety Recommendations for Evaluation and Surgery of the Head and Neck During the COVID-19 Pandemic. JAMA Otolaryngol Neck Surg. 2020 Mar 31. DOI: 10.1001/jamaoto.2020.0780. PubMed PMID: 32232423.

30. Lai C-C, Liu YH, Wang C-Y, Wang $Y-H$, Hsueh S-C, Yen M-Y, et al. Asymptomatic carrier state, acute respiratory disease, and pneumonia due to severe acute respiratory syndrome coronavirus 2 (SARS-CoV-2): Facts and myths. J Microbiol Immunol Infect. 2020 Mar 4; pii: S1684-1182(20)30040-2. DOI: 10.1016/j.jmii.2020.02.012. PubMed PMID: 32173241; PubMed Central PMCID: PMC7128959.

31. Li R, Pei $S$, Chen B, Song $Y$, Zhang $T$, Yang $W$, et al. Substantial undocumented infection facilitates the rapid dissemination of novel coronavirus (SARS-CoV2). Science 2020 May 1;368(6490):489-493. DOI: 10.1126/science.abb3221. PubMed PMID: 32179701; PubMed Central PMCID: PMC7164387.

32. World Health Organization (WHO) [Internet]. "Immunity passports" in the context of COVID-19. 2020 April 24 [Cited 2020 April 30]. Available from: https://www.who.int/news$\mathrm{room} /$ commentaries/detail/immunity-passports-in-the-context-of-covid-19

33. American Academy of Family Physicians [Internet]. Kansas: Checklist to Prepare Physician Offices for COVID-19. c2020 [cited 2020 Apr 29]. Available from: https://www.aafp.org/dam/ AAFP/documents/patient_care/public_health/COVID-19\%200ffice\%20Prep\%20Checklist. pdf

34. Republic of the Philippines: Department of Health and Department of the Interior and Local Government. [Internet]. Guidelines on Local Isolation and General Treatment Areas for COVID-19 Cases and the Community-based Management of Mild COVID-19 Cases. 2020 Ap 15 [cited 2020 Apr 29]. Available from: https://www.doh.gov.ph/sites/default/files/healthupdate/jao2020-0001_0.pdf

35. World Health Organization (WHO) [Internet]. Geneva: Coronavirus disease (COVID-19) advice for the public: When and how to use masks. c2020 [cited 2020 Apr 29]. Available from: https:// www.who.int/emergencies/diseases/novel-coronavirus-2019/advice-for-public/when-andhow-to-use-masks

36. US Centers for Disease Control and Prevention [Internet]. Recommendation Regarding the Use of Cloth Face Coverings, Especially in Areas of Significant Community-Based Transmission. Coronavirus Disease 2019 (COVID-19). c2020 [cited 2020 Apr 29]. Available from: https://www. cdc.gov/coronavirus/2019-ncov/prevent-getting-sick/cloth-face-cover.html

37. Singapore Ministry of Health [Internet]. Singapore: Continued Stringent Implementation \& Enforcement of Circuit Breaker Measures. 2020 Apr 14 [cited 2020 Apr 29]. Available from: https://www.moh.gov.sg/news-highlights/details/continued-stringent-implementationenforcement-of-circuit-breaker-measures

38. Republic of the Philippines: Inter-Agency Task Force for the Management of Emerging Infectious Diseases. [Internet] Recommendations Relative to the Management of the Coronavirus Disease 2019 (COVID-19) Situation, IATF Resolution No. 18 Series of 2020. 2020 April 1 [cited 2020 Apr 29]. Available from: https://www.doh.gov.ph/sites/default/files/ health-update/IATF-RESO-18.pdf

39. City Government of Makati. Resolutions and Ordinances 2020-089: An Ordinance Requiring All Persons Within the Territorial Jurisdiction of the City of Makati to Wear Face Masks or Other Similar Protective Equipment Outside their Home Premises. 2020 Apr 8 [cited 2020 Apr 29]. Available from: . https://www.makati.gov.ph/content/resolutions-and-ordinances/ search?query $=2020-089$

40. San Francisco Department of Public Health [Internet]. San Francisco: Preparing Your Office or Clinic for Potential COVID-19 (Novel Coronavirus) Patients. 2020 February 14 [cited 2020 April 29]. Available from: https://www.sfcdcp.org/wp-content/uploads/2020/02/Preparing-Clinicfor-COVID19-14Feb2020.pdf

41. Guo Z-D, Wang Z-Y, Zhang S-F, Li X, Li L, Li C, et al. Aerosol and surface distribution of severe acute respiratory syndrome coronavirus 2 in hospital wards, Wuhan, China. Emerg Infect Dis. 2020 Apr 10;26(7). DOI: 10.3201/eid2607.200885. PubMed PMID: 32275497.

42. Allen-Ehrhart T. How to Leave Coronavirus Behind When You Come Home [Internet]. Kansan:
FPM Journal Blog. 2020 Mar 30 [cited 2020 Apr 29]. Available from: https://www.aafp.org/ journals/fpm/blogs/inpractice/entry/covid19_home.html

43. Khunti K, Chan X-H, Ross L, et al. What is the evidence that COVID-19 personal protective equipment should include shoe covers? [Internet]. Oxford: The Centre for Evidence-Based Medicine 2020 Apr 7 [cited 2020 Apr 7]. Available from: https://www.cebm.net/covid-19/ what-is-the-evidence-that-covid-19-personal-protective-equipment-should-include-shoecovers/

44. Sweetmat Disinfection Mats [Internet]. New Zealand: Disinfectant options. [cited 2020 May 5] Available from: http://disinfectionmat.com/how-to-use-a-disinfection-mat/

45. Republic of the Philippines: Department of Health. [Internet] Department of Health Memorandum 2020-0157: Guidelines on Cleaning and Disinfection in Various Settings as an Infection Prevention and Control Measure Against COVID-19.2020 April 10 [cited 2020 May 5] Available from: https://www.doh.gov.ph/sites/default/files/health-update/dm2020-0157.pdf

46. US Centers for Disease Control and Prevention [Internet]. Atlanta: Guideline for Disinfection and Sterilization in Healthcare Facilities. 2008 (updated 2016 September 18) [cited 2020 May 5]. Available from: https://www.cdc.gov/infectioncontrol/guidelines/disinfection/ disinfection-methods/chemical.html

47. World Health Organization (WHO) [Internet]. Geneva: Is Wearing Rubber Gloves While Out in Public Effective in Preventing the New Coronavirus Infection? 2020 Mar 17 [cited 2020 Apr 29]. Available from: https://www.facebook.com/WHO/posts/q-is-wearing-rubber-gloves-whileout-in-the-public-effective-in-preventing-the-n/2988790457832984/

48. World Health Organization (WHO) [Internet]. Geneva: Management of ill travellers at points of entry-international airports, seaports and ground crossings-in the context of COVID-19 outbreak. 2020 Feb 16 [cited 2020 Apr 29]. Available from:_https://www.who.int/publications detail/management-of-ill-travellers-at-points-of-entry-international-airports-seaports-andground-crossings-in-the-context-of-covid--19-outbreak

49. Republic of the Philippines: Department of Health. [Internet] Reiteration of the Interim Guidelines on 2019 Novel Coronavirus Acute Respiratory Disease (2019-nCOV ARD) Response in the Workplace. 2020 Feb 5 [cited 2020 Apr 29]. Available from: https://www.doh.gov. $\mathrm{ph} /$ sites/default/files/health-update/DC2020-0039-Reiteration-of-DM2020-056-InterimGuidelines-on-2019-nCoV-ARD-Response-in-the-Workplace.pdf

50. United States Department of Labor Occupational Safety and Health Agency [Internet]. United States of America: Guidance on Preparing Workplaces for COVID-19 2020 Mar [cited 2020 Apr 29]. Available from: https://www.osha.gov/Publications/OSHA3990.pdf

51. Dudalski N., Mohamed A., Mubareka S, Bi R, Zhang C, Savory E. Experimental Investigation of Far Field Human Cough Airflows from Healthy and Influenza-Infected Subjects. Wiley Online Library. 2019 Nov 8. [cited 2020 Apr 30]. Available from: https://onlinelibrary.wiley.com/doi/ epdf/10.1111/ina.12680 DOI: 10.1111/ina.12680. PubMed PMID: 32304605.

52. Morawska L, Cao J. Airborne transmission of SARS-CoV-2: The world should face the reality. Environ Int. 2020 Jun 10. [cited 2020 Apr 30]. Available from: https://doi.org/10.1016/j. envint.2020.105730. PubMed PMID: 32294574; PubMed Central PMCID: PMC7151430.

53. Bahl P, Doolan C, de Silva C, Chughtai AA, Bourouiba L, Maclntyre CR. Airborne or Drople Precautions for Health Workers Treating Coronavirus Disease 2019? J Infect Dis. April 16, 2020 DOI: 10.1093/infdis/jiaa189. PubMed PMID: 32301491; PubMed Central PMCID: PMC7184471.

54. Tay J, Lim WS, Loh WS, Loh KS. Sustaining Otolaryngology services for the long haul during the COVID-19 Pandemic: Experience from a tertiary health system. Otolaryngol Head Neck Surg. 2020 May 5. [cited 2020 May 5]. Available from:https://doi.org/10.1177\%2F0194599820922983 DOI: $10.1177 / 0194599820922983$. PubMed PMID: 32366174

55. World Health Organization (WHO) [Internet]. Geneva: Standard Precautions in Health Care. 2007 Oct [cited 2020 Apr 29]. Available from: https://www.who.int/csr/resources/ publications/StandardPrectHC.pdf

56. US Centers for Disease Control and Prevention [Internet]. Atlanta: Respiratory Hygiene/Cough Etiquette in Healthcare Settings Seasonal Influenza (Flu). 2009 Aug 1 [cited Apr 29]. Available from: https://www.cdc.gov/flu/professionals/infectioncontrol/resphygiene.htm

57. Lifshitz E. Practical Healthcare Epidemiology, 4th Edition. Emerg Infect Dis. 2019 Nov;25(11):2161. DOI: 10.3201/eid2511.190464

58. United States Department of Labor Occupational Safety and Health Agency [Internet]. United States of America: Healthcare Workplaces Classified as Very High or High Exposure Risk for Pandemic Influenza. 2006 May [cited 2020 Apr 30]. Available from: https://www.osha.gov/ Publications/exposure-risk-classification-factsheet.html

59. US Centers for Disease Control and Prevention [Internet]. Atlanta: Interim Infection Prevention and Control Recommendations for Patients with Suspected or Confirmed Coronavirus Disease 2019 (COVID-19) in Healthcare Settings Coronavirus Disease 2019 (COVID-19). 2020 Apr 13 [cited 2020 May 5]. Available from: https://www.cdc.gov/coronavirus/2019-ncov/hcp/ infection-control-recommendations.htm

60. US Centers for Disease Control and Prevention [Internet]. Atlanta: Guidelines for Environmental Infection Control in Health-Care Facilities Environmental Infection Control Guidelines. 2003 [cited 2020 May 5]. Available from: https://www.cdc.gov/infectioncontrol/ guidelines/environmental/background/air.html

61. Minnesota Department of Health [Internet]. Minnesota: Airborne Infectious Disease Management - Methods for Temporary Negative Pressure Isolation. 2007 [cited 2020 May 5]. Available from: https://www.health.state.mn.us/communities/ep/surge/infectious/ airbornenegative.pdf

62. ENTHNSZCMC. Paving the way towards a "new normal." COVID-19: Efforts and Innovations March to April [Internet]. 2020 Apr 23 [cited 2020 April 23]. Available from: https://www. facebook.com/enthnszcmc/

63. Lu J, Gu J, Li K, Xu C, Su W, Lai Z, et al. COVID-19 Outbreak Associated with Air Conditioning in Restaurant, Guangzhou, China. Emerg Infect Dis. 2020 July [cited 2020 Apr 30]. Available from: https://doi.org/10.3201/eid2607.200764. PubMed PMID: 32240078. 


\section{REVIEW ARTICLE}

Philippine Journal Of Otolaryngology-Head And Neck Surgery

Vol. 35 No. 1 JANUARY - JUNE 2020

64. van Doremalen N, Morris D, Holbrook M, Gamble A, Williamson BN, Tamin A, et al. Aerosol and Surface Stability of SARS-CoV-2 as Compared with SARS-CoV-1. NEng/J Med. 2020 Apr 16 [cited 2020 Apr 29]. Available from: https://www.nejm.org/doi/full/10.1056/NEJMc2004973 DOI: 10.1056/NEJMc2004973. PubMed PMID: 32182409; PubMed Central PMCID: PMC7121658.

65. US Centers for Disease Control and Prevention [Internet]. Atlanta: Interim Recommendations for U.S. Community Facilities with Suspected/Confirmed Coronavirus Disease 2019 (COVID-19). 2020 Apr 1 [cited 2020 May 5]. Available from: https://www.cdc.gov/coronavirus/2019-ncov/ community/organizations/cleaning-disinfection.html

66. United States Environmental Protection Agency [Internet]. United States of America: List N Disinfectants for Use Against SARS-CoV-2 updated 2020 Apr 30 [cited 2020 May 6]. Available from: https://www.epa.gov/pesticide-registration/list-n-disinfectants-use-against-sars-cov-2

67. Chang CWD, Brenner MJ, Shuman EK, Kokoska MS. Reprocessing Standards for Medical Devices and Equipment in Otolaryngology: Safe Practices for Scopes, Speculums, and Single-Use Devices. Otolaryngol Clin North Am. 2019 Feb;52(1):173-183. DOI: 10.1016/j. otc.2018.08.014. PubMed PMID: 30262168.

68. US Food and Drug Authority [Internet]. United States of America: FDA-cleared sterilants and high level disinfectants with general claims for processing reusable medical and dental devices. 2015 Sep. [cited 2020 Apr 29]. Available from: https://www.fda.gov/medical-devices/ reprocessing-reusable-medical-devices-information-manufacturers/fda-cleared-sterilantsand-high-level-disinfectants-general-claims-processing-reusable-medical-and

69. US Centers for Disease Control and Prevention [Internet]. Atlanta: Miscellaneous Inactivating Agents Guideline for Disinfection and Sterilization in Healthcare Facilities (updated 2016 Sep 18) [cited 2020 May 5]. Available from: https://www.cdc.gov/infectioncontrol/guidelines/ disinfection/disinfection-methods/miscellaneous.htm

70. Knox RW, Demons ST, Cunningham CW. A Novel Method to Decontaminate Surgical Instruments for Operational and Austere Environments. Wilderness Environ Med. 2015 Dec;26(4):509-13. DOI: 10.1016/j.wem.2015.03.030. PubMed PMID: 26165581.

71. Martin SB, Dunn C, Freihaut JD, Bahnfleth WP, Lau J, Nedeljkovic-Davidovic A. Ultraviolet germicidal irradiation - current best practices. Ashrae J. 2008 Aug; 50(8):28-36. Available from: https://nebraska.pure.elsevier.com/en/publications/ultraviolet-germicidal-irradiationcurrent-best-practices

72. Storz The World of Endoscopy [Internet]. Hygiene: Maintenance, Sterilization, Storage Techniques. $2^{\text {nd }}$ Edition. 2013 Jan [cited 2020 Apr 30]. Available from: https://www.karlstorz. $\mathrm{com} / \mathrm{cps} / \mathrm{rde} / \mathrm{xbcr} / \mathrm{karlstorz}$ assets/ASSETS/3331303.pdf

73. Aeran H, Sharma S, Kumar V, Gupta N. Use of Clinical UV Chamber to Disinfect Dental Impressions: A Comparative Study. J Clin Diagn Res. 2015 Aug; 9(8): ZC67-ZC70. Published online 2015 Aug 1. DOI: 10.7860/JCDR/2015/14025.6353. PubMed PMID: 26436051; PubMed Central PMCID: PMC4576645.

74. Health Quality Ontario. Portable Ultraviolet Light Surface-Disinfecting Devices for Prevention of Hospital-Acquired Infections: A Health Technology Assessment. Ont Health Technol Assess Ser [Internet]. 2018 Feb;18(1):1-73 [cited 2020 Apr 3]. Available from: http://www.hqontario. ca/Portals/0/Documents/evidence/reports/hta-uv-light-1802-en.pdf

75. United States of America: U.S. Department of Health and Human Services Food and Drug Administration Center for Devices and Radiological Health. Enforcement Policy for Sterilizers, Disinfectant Devices, and Air Purifiers During the Coronavirus Disease 2019 (COVID-19) Public Health Emergency: Guidance for Industry and Food and Drug Administration Staff. March 2020 [cited 2020 May 5]. Available from: https://www.fda.gov/media/136533/download

76. Walker RW, Markillie LM, Colotelo AH, Gay ME, Woodley CM, Brown RS. The Efficacy of Ultraviolet Radiation for Sterilizing Tools Used for Surgically Implanting Transmitters into Fish. Draft Final Report. Pacific Northwest National Laboratory, Prepared for the U.S. Army Corps of Engineers, Portland District, under an Interagency Agreement with the U.S. Department of Energy Contract DE-AC05-76RL01830. 2012 Feb [cited 2020 May 5]. Available from: https:// waterpower.pnnl.gov/jsats/pdf/PNNL-21126.pdf

77. X X Y, Li X, Zhu B, Liang H, Fang C, Gong Y, et al. Characteristics of pediatric SARS-CoV-2 infection and potential evidence for persistent fecal viral shedding. Nat Med. 2020 Apr;26(4):502-505. DOI: 10.1038/s41591-区020-0817-4. PubMed PMID: 32284613; PubMed Central PMCID: PMC7095102.

78. Occhipinti V, Pastorelli L. Challenges in the Care of IBD Patients During the CoVid-19 Pandemic: Report From a "Red Zone" Area in Northern Italy. Inflamm Bowel Dis. 2020 Apr 21; pii: izaa084. DOI: 10.1093/ibd/izaa084. PubMed PMID: 32314792; PubMed Central PMCID: PMC7188155.

79. Johnson DA. Toilets may pose risk for spreading COVID 19. Medscape Commentary. $2020 \mathrm{Apr}$ 09 [cited 2020 May 6]. Available from: https://www.medscape.com/viewarticle/928234

80. Kurnitski J, Boerstra A, Franchimon F, Mazzarella L, Hogeling J, Hovorka F, et al. How to operate and use building services in order to prevent the spread of the coronavirus disease (COVID-19) virus (SARS-CoV-2) in workplaces [Internet]. Brussels: Federation of Heating, Ventilation and Air Conditioning Associations. Updated 2020 Apr 3 [cited 2020 May 5]. Available from: https://www.rehva.eu/fileadmin/user_upload/REHVA_COVID-19_guidance_document ver2_20200403_1.pdf

81. Singapore Ministry of Health and National Environment Agency [Internet]. Interim Guidelines for Environmental Cleaning and Disinfection of Areas Exposed to Confirmed Case(s) of COVID-19 in Non-Healthcare Premises. 2020 Jan 25, Revised 2020 Apr 29 [cited 2020 May 5]. Available from: https://www.nea.gov.sg/our-services/public-cleanliness/environmentalcleaning-guidelines/guidelines/guidelines-for-environmental-cleaning-and-disinfection

82. US Centers for Disease Control and Prevention [Internet]. Atlanta: Interim Laboratory Biosafety Guidelines for Handling and Processing Specimens Associated with Coronavirus Disease 2019 (COVID-19). 2020 Mar 31 [cited 2020 May 7]. Available from: https://www.cdc gov/coronavirus/2019-ncov/lab/lab-biosafety-guidelines.html)

83. Asian Development Bank [Internet]. Mandaluyong: Managing Infectious Medical Waste During the COVID-19 Pandemic. 2020 [cited 2020 May 07]. Available from: https://www.adb. org/sites/default/files/publication/578771/managing-medical-waste-covid19.pdf

84. Siwicki B. Telemedicine during COVID-19: Benefits, limitations, burdens, adaptation. In healthcareitnews.com [internet] 2020 March 19 [cited 2020 May 10]. Available from: https:// www.healthcareitnews.com/news/telemedicine-during-covid-19-benefits-limitationsburdens-adaptation

85. McCool RR, Davies L. Where Does Telemedicine Fit into Otolaryngology? An Assessment of Telemedicine Eligibility among Otolaryngology Diagnoses. Otolaryngol Head Neck Surg. 2018 Feb 13; 158 (4):641-644 DOI: 10.1177/0194599818757724. PubMed PMID 29436270.

86. American Academy of Otolaryngology - Head and Neck Surgery. Prioritizing Novel Approaches to Telehealth for All Practitioners From the AAO-HNS Telemedicine Committee - Douglas M. Hildrew, MD. 2020 March 18 [cited 2020 May 6]. Available from: https://www. entnet.org/content/prioritizing-novel-approaches-telehealth-all-practitioners

87. Department of Health - Philippines. [Internet] DOH Boosts Telemedicine Services For NCR; Service To Expand To Other Regions Soon. Press Release 2020 April 07 [cited 2020 May 10] Available from: https://www.doh.gov.ph/doh-press-release/DOH-BOOST-TELEMEDICINESERVICES-FOR-NCR-SERVICE-TO-EXPAND-TO-OTHER-REGIONS-SOON

88. University of the Philippines Padayon Public Service Office. [Internet] UP-PGH COVID-19 Operations Center Bayanihan Na website. [Cited 2020 May 10]. Available from: https:// publicservice.up.edu.ph/uppgh-bayanihan-na/

89. Centers for Disease Control and Prevention. [Internet] Outpatient and Ambulatory Care Settings: Responding to Community Transmission of COVID-19 in the United States. CDC. last reviewed 2020 April [Cited 2020 May 10]. Available from: https://www.cdc.gov/ coronavirus/2019-ncov/hcp/ambulatory-care-settings.html

90. World Health Organization (WHO) [Internet]. Atlanta: Infection prevention and control during health care when COVID-19 is suspected. 2020 [cited 2020 May 10]. Available from: https:// apps.who.int/iris/rest/bitstreams/1272420/retrieve

91. Philippine Society of Otolaryngology - Head and Neck Surgery [Internet]. Philippines: PSOHNS COVID-19 Advisory: Aerosol Generating Procedures in ORL-HNS PSO-HNS. 2020 [cited 2020 May 8]. Available from: https://www.facebook.com/PSOHNS.org/photos/rpp.151490160539 4714/2616827178535479/?type=3\&theater

92. American Healthcare Association National Center for Assisted Living [Internet]. COVID-19: Screening Checklist - for Visitors and Staff 2020 [cited 2020 May 5]. Available from: https:// www.ahcancal.org/facility_operations/disaster_planning/Documents/COVID19-ScreeningChecklist-SNF-Visitors.pdf

93. Couzin-Frankel J. Why don't some coronavirus patients sense their alarmingly low oxygen levels? [Internet]. American Association for the Advancement of Science. 2020 [cited 2020 May 5]. Available from: https://www.sciencemag.org/news/2020/04/why-don-t-somecoronavirus-patients-sense-their-alarmingly-low-oxygen-levels\#

94. Khalid A. Pulse oximeters are selling out because of the pandemic. Most people don't need them [Internet]. Quartz. 2020 [cited 2020 May 5]. Available from: https://qz.com/1832464/ pulse-oximeters-for-coronavirus-unnecessary-but-selling-strong/

95. Groth L. Pulse Oximeters May Be Helpful For People With COVID-19-Here's What to Know Before You Buy One. In Health.com [Internet] 2020 April 28 [cited 2020 May 10]. Available from: https://www.health.com/condition/infectious-diseases/coronavirus/pulse-oximeter

96. Department of Business Energy and Industrial Strategy, Public Health England [Internet]. London: Guidance for employers and businesses on coronavirus (COVID-19). 2020 [cited 2020 May 5]. Available from: https://www.gov.uk/government/publications/guidance-toemployers-and-businesses-about-covid-19/guidance-for-employers-and-businesses-oncoronavirus-covid-19

97. Centers for Disease Control and Prevention. [Internet] Cleaning and Disinfection for Households. CDC. last reviewed 2020 May 7 [Cited 20 May 10]. Available from: https://www. cdc.gov/coronavirus/2019-ncov/prevent-getting-sick/cleaning-disinfection.html

98. World Health Organization [Internet]. Geneva: Q\&A on coronaviruses (COVID-19). 2020 April 17 [Cited 2020 May 10]. Available from: https://www.who.int/emergencies/diseases/novelcoronavirus-2019/question-and-answers-hub/q-a-detail/q-a-coronaviruses

99. King R, Shen A. Will cash survive Covid-19? [Internet]. Infopro Digital Services Limited. 2020 [cited 2020 May 5]. Available from: https://www.centralbanking.com/central-banks/ currency/7509046/will-cash-survive-covid-19

100. World Health Organization [Internet]. Geneva: Health Topics: Can COVID-19 be spread through coins and banknotes? (Infographic on the web). 2020 April 17 [cited 2020 May 9] Available from: https://www.who.int/images/default-source/health-topics/coronavirus/engmythbusting-ncov-(23).tmb-1920v.png

101. Centers for Medicare \& Me. CMS Adult Elective Surgery and Procedures Recommendations [Internet]. 2020 [cited 2020 May 8]. Available from: https://www.cms.gov/files/document/ covid-elective-surgery-recommendations.pdf

102. Tantuco VL. Explainer:The PPE keeping our healthcare workers safe [Internet]. Manila: Rappler Inc.; c2020-21 (updated 2020 April 5) [cited 2020 May 8]. Available from: https://www.rappler. com/newsbreak/iq/256806-explainer-personal-protective-equipment-keeping-healthcareworkers-safe-coronavirus

103. Dofitas R, Say A, Lahoz E, De Leon J, Inso R, Aison D, et al. Recommendations for The Rational and Effective use Personal Protective Equipment [Internet]. Philippine College of Surgeons. 2020 [cited 2020 May 13]. Available from: http://pcs.org.ph/assets/images/PCS-COVID-10Rationale-Use-of-PPE.pdf

104. Health Protection Scotland. Best Practice - Aide memoire for Levels of Personal Protective Equipment (PPE) for Healthcare Workers when providing patient care [Internet]. 2020 Feb [cited 2020 Mar 25]. Available from: http://www.nipcm.hps.scot.nhs.uk/appendices/ appendix-16-best-practice-aide-memoire-for-levels-of-personal-protective-equipment-ppefor-healthcare-workers-when-providing-patient-care/

105. Wang J, Zhou M, Liu F. Reasons for healthcare workers becoming infected with nove 
coronavirus disease 2019 (COVID-19) in China. J Hosp Infect. 2020 Mar 6. DOI: 10.1016/j. jhin.2020.03.002. PubMed PMID: 32147406; PubMed Central PMCID: PMC7134479.

106. Remuzzi A, Remuzzi G. COVID-19 and Italy: what next? Lancet. 2020 Mar 12 [cited 2020 Ap 12]; 5(10231):1225-8. DOI: https://doi.org/10.1016/S0140-6736(20)30627-9. PubMed PMID: 32178769; PubMed Central PMCID: PMC7102589.

107. Minder R, Peltier E. Virus Knocks Thousands of Health Workers Out of Action in Europe. In: The New York Times. [Internet] 2020 March 24 [cited 2020 May 8]. Available from: https://www. nytimes.com/2020/03/24/world/europe/coronavirus-europe-covid-19.html

108. Royal College of Psychiatrists. [Internet] COVID-19: Personal Protective Equipment (PPE). Royal College of Psychiatrists. [cited 2020 May 11]. Available from: https://www.rcpsych.ac.uk/ about-us/responding-to-covid-19/responding-to-covid-19-guidance-for-clinicians/personalprotective-equipment-ppe

109. Cheng X, Liu J, Li N, Nisenbaum E, Sun Q, Chen B, et al. Otolaryngology Providers Must Be Alert for Patients with Mild and Asymptomatic COVID-19. Otolaryngol Head Neck Surg. 2020 Apr 14 [Epub ahead of print]. DOI: 10.1177/0194599820920649. PubMed PMID: 32286913.

110. Public Health England, Academy of Medical Royal Colleges, Public Health Wales, Health Protection Scotland, HSC Public Health Agency, NHS. Recommended PPE for primary, outpatient, community and social care by setting, NHS and independent sector. $2020 \mathrm{April}$ 4 [cited 2020 May 11]. Available from: https://assets.publishing.service.gov.uk/government/ uploads/system/uploads/attachment_data/file/878750/T2_poster_Recommended_PPE_ for_primary_outpatient_community_and_social_care_by_setting.pdf

111. World Health Organization. [Internet] Coronavirus disease 2019 (COVID-19) Situation Report - 662020 [cited 2020 May 8]. Available from: https://www.who.int/docs/default-source/ coronaviruse/situation-reports/20200326-sitrep-66-covid-19.pdf?sfvrsn=81 b94e61_2

112. World Health Organization. [Internet]. Rational use of personal protective equipment for coronavirus disease (COVID-19) and considerations during severe shortages. 2020 [cited 2020 May 8]. Available from: https://apps.who.int/iris/bitstream/handle/10665/331695/WHO2019-nCov-IPC_PPE_use-2020.3-eng.pdf

113. Health and Safety Executive UK. Research: review of personal protective equipment provided in health care settings to manage risk during the coronavirus outbreak [Internet]. HSE. 2020 [cited 2020 May 8]. Available from: https://www.hse.gov.uk/news/face-mask-equivalenceaprons-gowns-eye-protection-coronavirus.htm

114. US Centers for Disease Control and Prevention. Strategies for Optimizing the Supply of N95 Respirators [Internet]. CDC. 2020 [cited 2020 May 8]. Available from: https://www.cdc.gov/ coronavirus/2019-ncov/hcp/respirators-strategy/index.html

115. 3M Personal Safety Division. Technical Bulletin: Comparison of FFP2, KN95, and N95 and Other Filtering Facepiece Respirator Classes. Revision 3, 2020 May [cited 2020 May 11]. Available from: https://multimedia.3m.com/mws/media/17915000/comparison-ffp2-kn95-n95filtering-facepiece-respirator-classes-tb.pdf

116. Health and Safety Executive UK. Fit testing face masks to avoid transmission during the coronavirus outbreak [Internet]. HSE. 2020 [cited 2020 May 8]. Available from: https://www. hse.gov.uk/news/face-mask-ppe-rpe-coronavirus.htm

117. US Centers for Disease Control and Prevention. [Internet] Healthcare Respiratory Protection Resources. updated 2020 May 5 [cited 2020 May 11]. Available from: https://www.cdc.gov/ niosh/nppt//hospresptoolkit/programeval.html

118. US Centers for Disease Control and Prevention. [Internet] National Personal Protective Technology Laboratory, National Institute for Occupational Safety and Health. Ancillary Respirator Information. reviewed 2018 Jan 29 [cited 2020 May 11]. Available from: https:// www.cdc.gov/niosh/nppt//topics/respirators/disp_part/respsource3.html

119. Institute of Medicine. Preventing Transmission of Pandemic Influenza and Other Viral Respiratory Diseases: Personal Protective Equipment for Healthcare Personnel: Update 2010 (2011). Larson EL, Liverman CT (editors). Washington, DC: The National Academies Press; 2011. DOI: https://doi.org/10.17226/13027.

120. Magennis P, Kumar N, British Association of Oral and Maxillofacial Surgeons, ENT UK [Internet]. Guidance PPE for patients with emergency oropharyngeal and nasopharyngeal conditions whose COVID Status is unknown. ENT UK. 2020 March 25 [Cited 2020 May 11]. Available from: https://www.entuk.org/guidance-ppe-patients-emergency-oropharyngeal-andnasopharyngeal-conditions-whose-covid-status

121. Royal College of Surgeons. [Internet]. Aerosol-generating procedures in ENT. ENT UK. 2020 [cited 2020 May 8]. Available from: https://www.entuk.org/aerosol-generating-proceduresent

122. National Institute for Occupational Safety and Health. [Internet]. Recommended Guidance for Extended Use and Limited Reuse of N95 Filtering Facepiece Respirators in Healthcare Settings - NIOSH Workplace Safety and Health Topic. Pandemic Planning. 2020 [cited 2020 Apr 14]. Available from: https://www.cdc.gov/niosh/topics/hcwcontrols/ recommendedguidanceextuse.html

123. Patel ZM, Fernandez-Miranda J, Hwang PH, Nayak JV, Dodd RI, Sajjadi H, et al. Precautions For Endoscopic Transnasal Skull Base Surgery During the Covid-19 Pandemic. Neurosurgery. 2020 Apr 23. pii: nyaa156. DOI: 10.1093/neuros/nyaa156. PubMed PMID: 32323725; PubMed Central PMCID: PMC7188177.

124. ENT Today.org [Internet] Otolaryngologists May Contract COVID-19 During Surgery 2020 March 20 [cited 2020 May 8]. Available from: https://www.enttoday.org/article/ otolaryngologists-may-contract-covid-19-during-surgery/

125. Kowalski LP, Sanabria A, Ridge JA, Ng WT, de Bree R, Rinaldo A, et al. COVID-19 pandemic: Effects and evidence-based recommendations for otolaryngology and head and neck surgery practice. Head Neck. 2020 Apr 9 [Epub ahead of print] DOI: 10.1002/hed.26164. PubMed PMID: 32270581.

126. World Health Organization. [Internet] Advice on the use of masks in the community, during home care and in health care settings in the context of the novel coronavirus (2019-nCoV) outbreak. 2020 January 29 [cited 2020 Apr 30]. Available from: https:/www.who.int/docs/ default-source/documents/advice-on-the-use-of-masks-2019-ncov.pdf

127. Philippine General Hospital. Guide to Donning Personal Protective Equipment. [Internet] 2020 March 27 [cited 2020 May 12]. Available from: http://www.pgh.gov.ph/static/media/uploads/ covid19filesemployees/donning3272020.jpg

128. Philippine General Hospital. Guide to Doffing Personal Protective Equipment. [Internet] 2020 March 27 [cited 2020 May 12]. Available from: http://www.pgh.gov.ph/static/media/uploads/ covid19filesemployees/doffing3272020.jpg

129. Department of Surgery. PGH Surgery Donning and Doffing of PPE (Enhanced Version 6.1) [Internet]. Philippine General Hospital; 2020 April 4 [cited 2020 May 12]. Available from: https://www.youtube.com/watch?v=rvq63C5/YNc

130. US Centers for Disease Control and Prevention. [Internet] Protecting Healthcare Personnel 2014 August 18 [cited 2020 April 30]. Available from: https://www.cdc.gov/hai/prevent/ppe. $\mathrm{html}$

131. Department of Health - Philippines. [Internet]. Interim Guidelines on the Management of Health Care Waste in Health Facilities, Community Quarantine Units, and Temporary Treatment and Monitoring Facilities with Cases of Coronavirus Disease 2019 (COVID-19). 2020 April 2 [cited 2020 May 8]. Available from: https://www.doh.gov.ph/sites/default/files/healthupdate/dm2020-0170.pdf

132. Bauchner H, Fontanarosa PB, Livingston EH. Conserving Supply of Personal Protective Equipment-A Call for Ideas. JAMA 2020 Mar 20 [Epub ahead of print] DOI: 10.1001/ jama.2020.4770. PubMed PMID: 32196543

133. United States National Institutes of Health. [Internet]. Supplemental COVID Face Shield - Instructions for Use. C2020 [cited 2020 April 25]. Available from: https://3dprint.nih. gov/sites/default/files/models/supplemental_documentation/IFU_Face_Shield\%20_ Rev.1.1_03_30.20_0.pdf

134. National Science Teaching Association. [Internet]. Eye Protection and Safer practice FAQ 2020 [cited 2020 May 8]. Available from: http://static.nsta.org/pdfs/ EyeProtectionAndSaferPracticesFAO.pdf

135. United States Food and Drug Administration. [Internet]. Questions About Personal Protective Equipment (PPE). 2020 Mar 11 [cited 2020 April 15]. Available from: https://www.fda.gov/ medical-devices/personal-protective-equipment-infection-control/questions-aboutpersonal-protective-equipment-ppe

136. American Academy of Otolaryngology-Head and Neck Surgery [Internet]. Academy Supports CMS, Offers Specific Nasal Policy. 2020 March 18 [updated 2020 March 26; cited 2020 April 20]. Available from: https://www.entnet.org/content/academy-supports-cms-offers-specificnasal-policy

137. Bloomberg News [Internet]. Europe's Doctors Repeat Errors Made in Wuhan, China Medics Say. 2020 March 17 [cited 2020 April 20]. Available from: https:/www.bloomberg.com/news/ articles/2020-03-17/europe-s-doctors-getting-sick-like-in-wuhan-chinese-doctors-say

138. Lu D, Wang $\mathrm{H}, \mathrm{Yu}$, Yang $\mathrm{H}$, Zhao Y. Integrated infection control strategy to minimize nosocomial infection of coronavirus disease 2019 among ENT healthcare workers. J Hosp Infect. 2020 Apr;104(4):454-455. DOI: 10.1016/j.jhin.2020.02.018. PubMed PMID: 32114056; PubMed Central PMCID: PMC7124261.

139. Rothe C, Schunk M, Sothmann P, Bretzel G, Froeschl G, Wallrauch C, et al. Transmission of 2019nCoV Infection from an Asymptomatic Contact in Germany. N Engl J Med. 2020;382(10):970971. DOI: 10.1056/NEJMc2001468. PubMed PMID: 32003551; PubMed Central PMCID: PMC7120970.

140. Xu J, Li Y, Gan F, Du Y, Yao Y. Salivary Glands: Potential Reservoirs for COVID-19 Asymptomatic Infection. J Dent Res. 2020 Apr 9:22034520918518. DOl:10.1177/0022034520918518. PubMed PMID: 32271653.

141. Hu Z, Song $C, X u C$, Jin $G$, Chen $Y, X u X$, et al. Clinical characteristics of 24 asymptomatic infections with COVID-19 screened among close contacts in Nanjing, China. Sci China Life Sci. 2020;63(5):706-711. DOI:10.1007/s11427-020-1661-4. PubMed PMID: 32146694; PubMed Central PMCID: PMC7088568.

142. Philippine Society of Otolaryngology-Head and Neck Surgery and Philippine Academy of Rhinology [Internet]. A Friendly Reminder to Fellow ENTs \& Residents. 2020 March 22 [cited 2020 April 20]. Available from https://pso-hns.org/wp-content/uploads/2020/03/paradvisory-re-covid-no.-1.pdf

143. Lan L, Xu D, Ye G, Xia C, Wang S, Li Y, et al. Positive RT-PCR Test Results in Patients Recovered From COVID-19 [published online ahead of print, $2020 \mathrm{Feb}$ 27]. JAMA. $2020 \mathrm{Feb}$ 27;323(15):1502-1503. DOI: 10.1001/jama.2020.2783. PubMed PMID: 32105304; PubMed Central PMCID: PMC7047852.

144. Zou L, Ruan F, Huang M, Liang L, Huang H, Hong Z, et al. SARS-CoV-2 Viral Load in Upper Respiratory Specimens of Infected Patients. N Engl J Med. 2020 Mar 19;382(12):11771179. DOI:10.1056/NEJMc2001737. PubMed PMID: 32074444; PubMed Central PMCID: PMC7121626.

145. Leung, H. What We Know About Coronavirus Immunity and Reinfection. Time [Internet]. 2020 April 3 (updated 2020 April 13) [cited 2020 April 20]. Available from: https://time. com/5810454/coronavirus-immunity-reinfection/.

146. Yu P, Zhu J, Zhang Z, Han Y, Huang L. A familial cluster of infection associated with the 2019 novel coronavirus indicating potential person-to-person transmission during the incubation period. J Infect Dis. 2020 May 11;221(11):1757-1761. DOI:10.1093/infdis/jiaa077. PubMed PMID: 32067043; PubMed Central PMCID: PMC7107453.

147. Philippine Society of Otolaryngology - Head and Neck Surgery [Internet]. Endoscopy Guidelines during the COVID-19 Pandemic. 2020 March 22 [cited 2020 April 20]. Available from https://pso-hns.org/2020/03/22/endoscopy-guidelines-during-covid-19-pandemic/.

148. Jones RM, Brosseau LM. Aerosol transmission of infectious disease. J Occup Environ Med. 2015 
May;57(5):501-508. DOI:10.1097/JOM.0000000000000448. PubMed PMID: 25816216

149. Workman AD, Welling DB, Carter BS, Curry WT, Holbrook EH, Gray ST, et al. Endonasal instrumentation and aerosolization risk in the era of COVID-19: simulation, literature review, and proposed mitigation strategies. Int Forum Allergy Rhinol. 2020 Apr 3;10.1002/alr.22577. DOI: 10.1002/alr.22577. PubMed PMID: 32243678.

150. Asadi S, Wexler AS, Cappa CD, Barreda S, Bouvier NM, Ristenpart WD. Aerosol emission and superemission during human speech increase with voice loudness. Sci Rep. 2019 Feb 20;9(1):2348. Published 2019 Feb 20. DOI: 10.1038/s41598-019-38808-z. PubMed PMID: 30787335; PubMed Central PMCID: PMC6382806

151. Tateda, K. Coronavirus: New Facts about Infection Mechanisms - NHK Documentary [Internet]. 2020 April 3 [cited 2020 April 24]. Available from: https://www.youtube.com/ watch? $\mathrm{v}=\mathrm{H} 2 \mathrm{azcn} 7 \mathrm{MqOU}$

152. Lanese, N. COVID-19 may spread through breathing and talking - but we don't know how much [Internet]. 2020 April 7 [cited 2020 April 7]. Available from: https://www.livescience. com/covid19-coronavirus-transmission-through-speech.html

153. Wang J, Du G. COVID-19 may transmit through aerosol. Ir J Med Sci. 2020 Mar 24;1-2. DOI:10.1007/s11845-020-02218-2. PubMed PMID 32212099; PubMed Central PMCID: PMC7094991.

154. Asadi S, Bouvier N, Wexler AS, Ristenpart WD. The coronavirus pandemic and aerosols: Does COVID-19 transmit via expiratory particles? Aerosol Sci Technol. 2020 Apr 3; 54:6, 635-638. DOI: 10.1080/02786826.2020.1749229. PubMed PMID: 32308568; PubMed Central: PMC7157964.

155. Bloustine S, Langston L, Miller T. Ear-cough (Arnold's) reflex. Ann Otol Rhinol Laryngol. 1976 May 1;85(3 pt 1):406-407. DOI: 10.1177/000348947608500315. PubMed PMID: 937970.

156. Gupta D, Verma S, Vishwakarma SK. Anatomic basis of Arnold's ear-cough reflex. Surg Radiol Anat. 1986;8(4):217-220. DOI: 10.1007/bf02425070. PubMed PMID: 3107144

157. World Health Organization (WHO) [Internet]. Atlanta: Coronavirus disease (COVID-19) advice for the public. 2020 March 31 [cited 2020 April 29]. Available from: https://www.who.int/ emergencies/diseases/novel-coronavirus-2019/advice-for-public

158. National Center for Immunization and Respiratory Diseases (NCIRD), Division of Viral Diseases US Centers for Disease Control and Prevention [Internet]. United States of America: Social Distancing, Quarantine, and Isolation. 2020 April 4 [cited 2020 April 29]. Available from: https://www.cdc.gov/coronavirus/2019-ncov/prevent-getting-sick/social-distancing.html

159. Shaw S, Wherton J, Vijayaraghavan S, Morris J, Bhattacharya S, Hanson P, et al. Advantages and limitations of virtual online consultations in an NHS acute trust: the VOCAL mixed-methods study. Health Serv Deliv Res 2018;6(21). DOI: 10.3310/hsdr06210. PubMed PMID: 29939519.

160. Jegoux F, Legent F, Beauvillain de Montreuil C. Chronic cough and ear wax [published correction appears in Lancet 2002 Oct 19;360(9341):1256]. Lancet. 2002 Aug 24;360(9333):618. DOI: 10.1016/s0140-6736(02)09786-6. PubMed PMID: 12241935.

161. Saadi RA, Bann DV, Patel VA, Goldenberg D, May J, Isildak H. A Commentary on Safety Precautions for Otologic Surgery during the COVID-19 Pandemic. Otolaryngol Head Neck Surg. 2020 April 14:019459982091974. DOI:10.1177/0194599820919741. PubMed PMID: 32286916.

162. Pitkäranta A, Jero J, Arruda E, Virolainen A, Hayden FG. Polymerase chain reaction-based detection of rhinovirus, respiratory syncytial virus, and coronavirus in otitis media with effusion. J Pediatr. 1998 Sep;133(3):390-394. DOI: 10.1016/s0022-3476(98)70276-8. PubMed PMID: 9738723; PubMed Central PMCID: PMC7095025.

163. Rea P, Lloyd S, Jenkins D. Guidance for undertaking otological procedures during COVID-19 pandemic [Internet]. ENT UK. 2020 [cited 2020 April 13]. Available from: https://www.entuk. org/guidance-undertaking-otological-procedures-during-covid-19-pandemic

164. Jackler RK. Commentary: COVID-19 and Ear Surgery [Internet]. ENT UK. 2020 [cited 2020 April 13] Available from: https://www.entnet.org/sites/default/files/uploads/covid-19_and_ear_ surgery rk jackler_stanford.pdf

165. Davies E, Hopkins C, Harries P, Walker A, Heward E. ENT-UK COVID-19 Epistaxis Management [Internet]. ENT UK. 2020 [cited 2020 May 9]. Available from: https://www.entuk.org/sites/ default/files/files/COVID\%2019\%20Epistaxis\%20Management.pdf

166. Philippine Society of Otolaryngology Head and Neck Surgery [Internet]. Advisory No. 4 Algorithm for ENT-HNS Covid-19 Epistaxis Management from the Philippine Academy of Rhinology (PAR). 2020 April 14 [cited 2020 May 10]. Available from: https://pso-hns. org/2020/04/14/par-advisory-no-2-on-epistaxis/.

167. Royal College of Paediatrics and Child Health and British Paediatric Allergy Immunity \& Infection Group [Internet]. COVID-19 - guidance for paediatric services. 2020 March 13 (updated 2020 April 9) [cited 2020 April 22]. Available from: https://www.rcpch.ac.uk/sites/ default/files/generated-pdf/document/COVID-19---guidance-for-paediatric-services.pdf

168. Primary Care Critical Trials Unit [Internet]. Fever PAIN Clinical Score. [cited 2020 April 29]. Available from: https://ctu1.phc.ox.ac.uk/feverpain/index.php

169. Tang YC. Modified Centor Score for Streptococcal Pharyngitis (M-CENTOR) [Internet]. [cited 2020 April 29] Available from: https://canadiem.org/tiny-tips-modified-centor-score/.

170. McNally G, Burgess A, Agrawal S, Ismail Koch H, Elgan-Davies J, Paul J. ENT UK COVID-19 Tonsillitis and Quinsy Guidelines [Internet]. ENT UK. 2020 [cited 2020 May 9]. Available from: https://www.entuk.org/sites/default/files/files/ENT_UK_COVID_19_tonsillitis_and_quinsy_ guidelines.pdf

171. Davies E, Roland N. Nasal endoscopy and laryngoscopy examination of ENT patients [Internet]. 2020 March 23 [cited 2020 April 13]. Available from: https://www.entuk.org/sites/ default/files/files/Nasal\%20endoscopy\%20and\%20laryngoscopy\%20examination\%20of\%20 ENT\%20patients_compressed.pdf

172. Rameau A, Young VN, Amin MR, Sulica L. Flexible Laryngoscopy and COVID-19. Otolaryngol Head Neck Surg. 2020 April 21:194599820921395. DOl: 10.1177/0194599820921395. PubMed: PMID: 32312166

173. Everington, K. Taiwanese doctor invents device to protect US doctors against coronavirus, Taiwan News [Internet]. 2020 March 23 [cited 2020 April 23] Available from: https://www. taiwannews.com.tw/en/news/3902435

174. Canelli R, Connor CW, Gonzalez M, Nozari A, Ortega R. Barrier Enclosure during Endotracheal Intubation. N Engl J Med. 2020 Apr 3; NEJMc2007589. DOI:10.1056/NEJMc2007589. PubMed PMID: 32243118; PubMed Central PMCID: PMC7151333.

175. Your Design Medical. [Website] Creating a Biohazard Space for COVID19 Intubation: A covid intubation tent / box. 2020 March 23 [cited 2020 April 26]. Available from: https:// yourdesignmedical.com/blogs/making-a-safe-intubation-space-for-covid19/creating-abiohazard-space

176. Under the Scope. In face of COVID-19, ENT resident develops new devices, Facebook page to help healthcare workers [Internet]. 2020 April 9 [cited 2020 April 26]. Available from: https:// oto.wustl.edu/in-face-of-covid-19-ent-resident-develops-new-devices-facebook-page-tohelp-healthcare-workers/.

177. Vatanasapt P. Necessity is the mother of invention!! DIY: "Endoscopy Salon" [Internet]. 2020 April 1 [cited 2020 April 23]. Available from: https://www.facebook.com/patravoot/ videos/3399277473422865/.

178. US Centers for Disease Control and Prevention [Internet]. Disinfection and Sterilization. 2008 [cited 2020 April 28]. Available from: https://www.cdc.gov/infectioncontrol/guidelines/ disinfection/.

179. The National Academies of Sciences [Internet]. Does ultraviolet light kill the coronavirus 2020 April 22 [cited 2020 April 30]. Available from: https://sites.nationalacademies.org/ BasedOnScience/covid-19-does-ultraviolet-light-kill-the-coronavirus/index.htm

180. American College of Surgeons [Internet]. COVID-19: Guidance for Triage of Non-Emergent Surgical Procedures. 2020 [cited 2020 May 8]. Available from: https://www.facs.org/covid-19/ clinical-guidance/triage

181. Vilag L, Vilag V. Healthy Diet to Combat COVID19 [Internet]. 2020 [cited 2020 May 1]. Available from: http://www.paase.org/downloads/PAASE Bulletin 7.pdf

182. Grosso G, Bella F, Godos J, Sciacca S, Del Rio D, Ray S, et al. Possible role of diet in cancer: systematic review and multiple meta-analyses of dietary patterns, lifestyle factors, and cancer risk. Nutr Rev. 2017 Jun 1;75(6):405-419. DOI: 10.1093/nutrit/nux012. PubMed PMID: 28969358.

183. Eggers M. Infectious Disease Management and Control with Povidone lodine. Infect Dis Ther. 2019 Dec;8(4):581-593. DOI: 10.1007/s40121-019-00260-x. PubMed PMID:31414403; PubMed Central PMCID: PMC6956232 [Correction to: Infectious Disease Management and Control with Povidone lodine. Infect Dis Ther. 2019 Dec;8(4):595. DOI: 10.1007/s40121-019-00263-8. PubMed PMID: 31440901; PubMed Central PMCID: PMC6856231.]

184. Kariwa H, Fujii N, Takahima I. Inactivation of SARS coronavirus by means of povidone-iodine, physical conditions and chemical agents. Dermatology. 2006; 212 Suppl1: 119-23. DOI: 10.1159/000089211. PubMed PMID: 16490989; PubMed Central PMCID: PMC7179540.

185. Kampf G, Todt D, Pfaender S, Steinmann E. Persistence of coronaviruses on inanimate surfaces and their inactivation with biocidal agents. J Hosp Infect. 2020 Mar;104(3):246-251. DO 10.1016/j.jhin.2020.01.022. PubMed PMID: 32035997; PubMed Central PMCID: PMC7132493.

186. Monthly Index of Medical Specialties [Internet]. Betadine Gargle \& Paint/Betadine Throat Spray [cited 2020 Apr 20]. Available from: https://www.mims.com/philippines/drug/info/ betadine $\% 20$ gargle $\% 20$ and\%20paint-betadine $\% 20$ throat $\% 20$ spray

187. Mady LJ, Kubik MW, Baddour K, Snyderman CH, Rowan NR. Consideration of povidone-iodine as a public health intervention for COVID-19: Utilization as "Personal Protective Equipment" for frontline providers exposed in high-risk head and neck and skull base oncology care. Oral Oncol. 2020 Apr 16;104724. DOI: 10.1016/j.oraloncology.2020.104724. PubMed PMID: 32317139; PubMed Central PMCID: PMC7161480.

188. Concepcion G. (personal communication, with permission). Vit-C Protect ${ }^{\mathrm{TM}}$ naso-oral drops with $1.5 \mathrm{mg} / \mathrm{ml}$ Vitamin C. BIOGENINS ${ }^{\text {TM }} 2020$ May 2 [cited 2020 May 2].

189. Talbot AR, Herr TM, Parsons DS. Mucociliary clearance and buffered hypertonic saline solution Laryngoscope. 1997 Apr;107(4):500-3. DOI: 10.1097/00005537-1997040000-00013. PubMed PMID: 9111380.

190. Kaliner M. Medical management of sinusitis. Am J Med Sci. 1998 Jul;316(1):21-8. DOl: 10.1097/00000441-199807000-00004

191. Bishop JM, Maldonado RL, Garry RF, Allen PT, Bose HR, Waite MR. Effect of medium of lowered $\mathrm{NaCl}$ concentration on virus release and protein synthesis in cells infected with reticuloendotheliosis virus. J Virol. 1976 Feb;17(2):446-52. PubMed PMID: 176425; PubMed Central PMCID: PMC515436.

192. Tsurumi T, Aoki H, Nishiyama Y, Shibata M, Maeno K, Seo H. Effect of high salt treatment on influenza B viral protein synthesis in MDCK cells. Microbiol Immunol. 1983;27(6):519-29. DOI: 10.1111/j.1348-0421.1983.tb00613.x. PubMed PMID: 6195511.

193. Ramalingam S, Graham C, Dove J, Morrice L, Sheikh A. A pilot, open labelled, randomised controlled trial of hypertonic saline nasal irrigation and gargling for the common cold. Sci Rep. 2019 Jan 31;9(1):1015. DOI: 10.1038/s41598-018-37703-3. PubMed PMID: 30705369; PubMed Central PMCID: PMC6355924.

194. Min YG, Lee KS, Yun JB, Rhee CS, Rhyoo C, Koh YY, et al. Hypertonic saline decreases ciliary movement in human nasal epithelium in vitro. Otolaryngol Head Neck Surg. 2001 Mar;124(3):313-6. DOI: 10.1067/mhn.20001.113145. PubMed PMID: 11240998.

195. Hennet T, Peterhans E, Stocker R. Alterations in antioxidant defences in lung and liver of mice infected with influenza A virus. J Gen Virol. 1992 Jan;73(Pt1):39-46. DOI: 10.1099/0022-1317 73-1-39. PubMed PMID: 1530963.

196. Jiao J, Meng N, Wang H, Zhang L. The effects of vitamins $C$ and $B 12$ on human nasal ciliary beat frequency. BMC Complement Altern Med. 2013 May 20;13(110). DOI: 10.1186/1472-6882-13110. PubMed PMID: 23688196; PubMed Central PMCID: PMC3663725.

197. Gorton HC, Jarvis K. The effectiveness of vitamin C in preventing and relieving the symptoms of virus-induced respiratory infections. J Manipulative Physiol Ther. 1999 Oct;22(8):530-3. DO 10.1016/s0161-4754(99)70005-9. PubMed PMID: 10543583. 
REVIEW ARTICLE

198. Nahas R, Balla A. Complementary and alternative medicine for prevention and treatment of the common cold. Can Fam Physician. 2011 Jan;57(1):31-6. PubMed PMID: 21322286; PubMed Central PMCID: PMC3024156.

199. Dayrit F, Newport M. The Potential of Coconut Oil and its Derivatives as Effective and Safe Antiviral Agents Against the Novel Coronavirus (nCoV-2019). [Internet]. Ateneo De Manila University School of Science and Engineering. 2020. Available from: http://ateneo.edu/ Is/sose/sose/news/research/potential-coconut-oil-and-its-derivatives-effective-and-safeantiviral

200. Sands JA, Auperin LD, Reinhardt A. Enveloped virus inactivation by fatty acid derivatives. Antimicrob Agents Chemother. 1979 Jan;15(1):134-6. DOI: 10.1128/AAC.15.1.134. PubMed PMID: 218498; PubMed Central PMCID: PMC352613.

201. Tan-Lim CS, Martinez CV. Should Virgin Coconut Oil be used in the adjunctive treatment of COVID-19? [Internet]. Asia Pacific Center For Evidence Based Healthcare. 2020 [cited 2020 May 11]. Available from: https://www.psmid.org/should-virgin-coconut-oil-be-used-in-theadjunctive-treatment-of-covid-19/

202. Lin P-H, Sermersheim M, Li H, Lee PHU, Steinberg SM, Ma J. Zinc in Wound Healing Modulation Nutrients. 2017 Dec 24;10(1):16. DOI: 10.3390/nu10010016. PubMed PMID: 29295546; PubMed Central PMCID: PMC5793244.

203. Healthline [Internet]. The 10 Best Foods That Are High in Zinc. 2018 [cited 2018 Apr 30]. Available from: https://www.healthline.com/nutrition/best-foods-high-in-zinc

204. Zhang Y, Li X, Grailer JJ, Wang N, Wang M, Yao J, et al. Melatonin alleviates acute lung injury through inhibiting the NLRP3 inflammasome. J Pineal Res. 2016 May;60(4):405-14. DOI: 10.1111/jpi.12322. PubMed PMID: 26888116.

205. Abat ME, Larracas C, Cabaluna IT. Should Vitamin C/ Ascorbic Acid be used in the treatment of COVID-19? 2020 April 1, updated 2020 May 6. UP Institute of Clinical Epidemiology and Asia-Pacific Center for Evidence-Based Healthcare Rapid Evidence Reviews on COVID-19 Management: Treatment [Internet] Hosted by the Philippine Society for Microbiology and Infectious Diseases (PSMID). University of the Philippines Asia Pacific Center for Evidence Based Medicine. [cited 2020 May 10]. Available from: https://www.psmid.org/rapid-reviewvitamin-c/

206. Hemilä H, Chalker E. Vitamin C for preventing and treating the common cold. Cochrane database Syst Rev. 2013 Jan 31;(1):CD000980. DOI: 10.10002/14651858.CD000980.pub4. PubMed PMID: 23440782

207. Skalny A V, Rink L, Ajsuvakova OP, Aschner M, Gritsenko VA, Alekseenko SI, et al. Zinc and respiratory tract infections: Perspectives for COVID19 (Review). Int J Mol Med. 2020 Apr 14. DOI: 10.3892/ijmm.2020.4575. PubMed PMID: 32319538

208. Eubanas GS. Should Zinc be used in the treatment of COVID-19? [Internet]. Asia Pacific Center For Evidence Based Healthcare. 30 March 2020, updated 2020 April 2. UP Institute of Clinical Epidemiology and Asia-Pacific Center for Evidence-Based Healthcare Rapid Evidence Reviews on COVID-19 Management:Treatment [Internet] Hosted by the Philippine Society for Microbiology and Infectious Diseases (PSMID). University of the Philippines Asia Pacific Center for Evidence Based Medicine. [cited 2020 May 11]. Available from: https://www.psmid.org/ rapid-review-zinc/

209. Ilie PC, Stefanescu S, Smith L. The Role of Vitamin D in the prevention of Coronavirus Disease 2019 infection and mortality. Aging Clin Exp Res. 2020 May 6;1-4 DOI: 10.1007/s40520-02001570-8. PubMed PMID: 32377965; PubMed Central PMCID: PMC7202265

210. Garcia AMVP, Cabaluna I. Should melatonin be used as prophylaxis for COVID- 19? 2020 April 2, updated 2020 April 2. UP Institute of Clinical Epidemiology and Asia-Pacific Center for Evidence-Based Healthcare Rapid Evidence Reviews on COVID-19 Management: Prophylaxis [Internet] Hosted by the Philippine Society for Microbiology and Infectious Diseases (PSMID). University of the Philippines Asia Pacific Center for Evidence Based Medicine. [cited 2020 May 10] Available from: https://www.psmid.org/rapid-review-melatonin/

211. Lam HS, Chow CM, Poon WT, Lai CK, Chan KCA, Yeung WL, et al. Risk of Vitamin A Toxicity from Candy-Like Chewable Vitamin Supplements for Children. Pediatrics. 2006 Aug 1;118(2):820-4. DOI: 10.1542/peds.2006-0167. PubMed PMID: 16882846

212. Urivetzky M, Kessaris D, Smith AD. Ascorbic Acid Overdosing: A Risk Factor for Calcium Oxalate Nephrolithiasis. J Urol. 1992 May 1;147(5):1215-8. DOl: 10.1016/s0022-5347(17)37521-3. PubMed PMID: 1569652.

213. Shively RM, Harding SA, Hoffman RS, Hill AD, Astua AJ, Manini AF. Rebound metabolic acidosis following intentional amygdalin supplement overdose. Clin Toxicol (Phila). $2020 \mathrm{Apr}$ 2;58(4):290-293. DOI: 10.1080/15563650.2019.1640369. PubMed PMID: 31322009.

214. Lee K. COVID-19 Prophylaxis in Healthcare workers [Internet]. 2020 [cited 2020 Apr 30]. Available from: https://keleefitness.com/covid-19-prophylaxis-in-healthcare-workers/

215. Glenza J. Online demand for hydroxychloroquine surged 1,000\% after Trump backed it, study finds [Internet]. The Guardian. 2020 [cited 2020 May 5]. Available from: https://www. theguardian.com/world/2020/apr/29/online-demand-for-hydroxychloroquine-surged-1000after-trump-backed-it-study-finds

216. Gautret $P$, Lagier J-C, Parola P, Hoang VT, Meddeb L, Mailhe M, et al. Hydroxychloroquine and azithromycin as a treatment of COVID-19: results of an open-label non-randomized clinical trial. Int J Antimicrob Agents. 2020 Mar 20;105949. DOI: 10.1016/j.ijantimicag.2020.105949. PubMed PMID: 32205204; PubMed Central PMCID: PMC7102549.

217. Marchionne M. Nationwide Study Finds Malaria Drug Touted by President Trump Led to More Deaths, No Benefits in Coronavirus Patients. [Internet] Time. 2020 [cited 2020 May 8]. Available from: https://time.com/5825398/hydroxychloroquine-study-coronavirus/

218. US Food and Drug Administration [Internet]. United States of America: FDA cautions against use of hydroxychloroquine or chloroquine for COVID-19 outside of the hospital setting or a clinical trial due to risk of heart rhythm problems. 2020 [cited 2020 May 5]. Available from: https://www.fda.gov/drugs/drug-safety-and-availability/fda-cautions-against-usehydroxychloroquine-or-chloroquine-covid-19-outside-hospital-setting-or
219. Palileo-Villanueva LM, Villanueva CA, Uy E. Should Hydroxychloroquine (HCQ) or Cholroquine (CQ) be used in the treatment of Covid-19? 2020 March 31, updated 2020 April 10. UP Institute of Clinical Epidemiology and Asia-Pacific Center for Evidence-Based Healthcare Rapid Evidence Reviews on COVID-19 Management: Treatment [Internet] Hosted by the Philippine Society for Microbiology and Infectious Diseases (PSMID). University of the Philippines Asia Pacific Center for Evidence Based Medicine. [cited 2020 May 10] Available from: https://www. psmid.org/rapid-review-hydroxychloroquine-hcq-or-chloroquine-cq-treatment/

220. Tolosa MT. Should hydroxychloroquine with azithromycin be used in the treatment of COVID-19? 2020 March 31, updated 2020 March 31. UP Institute of Clinical Epidemiology and Asia-Pacific Center for Evidence-Based Healthcare Rapid Evidence Reviews on COVID-19 Management: Treatment [Internet] Hosted by the Philippine Society for Microbiology and Infectious Diseases (PSMID). University of the Philippines Asia Pacific Center for Evidence Based Medicine. [cited 2020 May 10] Available from: https://www.psmid.org/rapid-reviewhydroxychloroquine-with-azithromycin/

221. Branswell H. Why a decades-old TB vaccine is getting attention in the fight against Covid-19? [Internet]. Massachusetts: STAT. 2020 April 14 [cited 2020 May 10, 2020]. Available from: https://www.statnews.com/2020/04/14/decades-old-tb-vaccine-attracts-attention-andskepticism-as-a-potential-weapon-against-covid-19/

222. Soliman R, Brassey J, Plüddemann A, Heneghan C. Does BCG vaccination protect against acute respiratory infections and COVID-19? A rapid review of current evidence [Internet]. CEBM. 2020 [cited 2020 May 5]. Available from: https://www.cebm.net/covid-19/does-bcg vaccination-protect-against-acute-respiratory-infections-and-covid-19-a-rapid-review-ofcurrent-evidence/

223. Sanchez-Mostiero D, Melicor A. Should Bacillus Calmette-Guerin (BCG) vaccine be used as prophylaxis for COVID-19? Asia Pacific Center for Evidence Based Healthcare [Internet] University of the Philippines Asia Pacific Center for Evidence Based Medicine. 2020 [cited 2020 May 5]. Available from: https://www.psmid.org/rapid-review-bcg-vaccine/

224. Murdoch Children's Research Institute [Internet]. BCG Vaccination to Protect Healthcare Workers Against COVID-19. 2020. [cited 2020 May 10]. Available from: https://clinicaltrials. gov/ct2/show/NCT04327206

225. Centers for Disease Control and Prevention [Internet]. Atlanta: Influenza (Flu) Guidance: Outbreak Management in Long-Term Care Facilities; [updated 2019 November 18; cited 2020 May 10]. Available from: https://www.cdc.gov/flu/professionals/infectioncontrol/tc-facilityguidance.htm

226. World Health Organization [Internet]. Geneva: Q\&A: Similarities and differences - COVID-19 and influenza. 2020 March 17 [cited 2020 April 30]. Available from: https://www.who.int/ emergencies/diseases/novel-coronavirus-2019/question-and-answers-hub/q-a-detail/q-asimilarities-and-differences-covid-19-and-influenza

227. World Health Organization [Internet]. Geneva: Update on WHO Solidarity Trial - Accelerating a safe and effective COVID-19 vaccine. 2020 [cited 2020 May 5]. Available from: https:// www.who.int/emergencies/diseases/novel-coronavirus-2019/global-research-on-novelcoronavirus-2019-ncov/solidarity-trial-accelerating-a-safe-and-effective-covid-19-vaccine

228. Callaway E. The race for coronavirus vaccines: a graphical guide [Internet]. Nature. 2020 Apr;580(7805):567-577. [cited 2020 May 11]. Available from: https://www.nature.com/ articles/d41586-020-01221-y _DOI: 10.1038/d41586-020-01221-y. PubMed PMID: 32346146.

229. Biorender [Internet]. Toronto: Covid-19 Vaccine \& Therapeutics Tracker [cited 2020 May 11]. Available from: https://biorender.com/covid-vaccine-tracker?utm campaign=Vaccine+Tra cker\%3A+Announce\&utm_content=COVID-19+Vaccine+Tracker\%3A+Announcement\&u tm_medium=email_action\&utm_source=customer.io

230. Wu A, Connors C, Everly G Jr. COVID-19 Peer Support and Crisis Communication Strategies to Promote Institutional Resilience. Ann Intern Med. 2020 Apr 6; M20-1236 [Epub ahead of print] DOI:10.7326/M20-1236. PubMed PMID: 32251512; PubMed Central PMCID: PMC7146593.

231. Berg S. Peer support program strives to ease distress during pandemic. American Medical Association Practice Management: Physician Health. 2020 Apr 14 [cited 2020 April 16]. Available from: https://www.ama-assn.org/practice-management/physician-health/peersupport-program-strives-ease-distress-during-pandemic

232. Dewey C, Hingle S, Goelz E, Linzer M. Supporting Clinicians During the COVID-19 Pandemic Ann Intern Med. 2020 Mar 20; M20--1033 DOI: 10.7326/M20-1033. PubMed PMID:32196544 PubMed Central PMCID: PMC7106065.

233. Blythe WR, Shapiro JA, Wei JL. AAO-HNS Coronavirus Disease (COVID-19) Podcast Series Episode 6: ENTs Personal COVID-19 Experiences: Managing Your Wellness. [Internet] American Academy of Otolaryngology Head and Neck Surgery. 2020 Apr 3. [cited 2020 April 16]. Available from: https://www.entnet.org/content/covid-19-podcast-series

234. Rappler.com [Internet]. LIST: Groups providing free online counseling during the pandemic 2020 April 11 [cited 2020 April 23]. Available from: https://www.rappler.com/move$\mathrm{ph} / 257641$-list-groups-providing-free-online-counseling-during-the-pandemic 